\title{
Combining ecosystem modeling with serious gaming in support of transboundary maritime spatial planning
}

\author{
$\underline{\text { Jeroen Steenbeek }}^{1}$, Giovanni Romagnoni $^{2,3}, \underline{\text { Jacob W. Bentlev }}^{4}, \underline{\text { Johanna J. Hevmans }}^{4,5}, \underline{\text { Natalia Serpetti }}^{4}$, Magali Goncalves $^{6}, \underline{\text { Carlos }}$

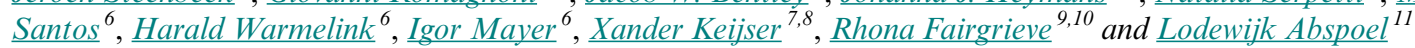

\begin{abstract}
The Maritime Spatial Planning (MSP) Challenge simulation platform helps planners and stakeholders understand and manage the complexity of MSP. In the interactive simulation, different data layers covering an entire sea region can be viewed to make an assessment of the current status. Users can create scenarios for future uses of the marine space over a period of several decades. Changes in energy infrastructure, shipping, and the marine environment are then simulated, and the effects are visualized using indicators and heat maps. The platform is built with advanced game technology and uses aspects of role-play to create interactive sessions; it can thus be referred to as serious gaming. To calculate and visualize the effects of planning decisions on the marine ecology, we integrated the Ecopath with Ecosim (EwE) food web modeling approach into the platform. We demonstrate how EwE was connected to MSP, considering the range of constraints imposed by running scientific software in interactive serious gaming sessions while still providing cascading ecological feedback in response to planning actions. We explored the connection by adapting two published ecological models for use in MSP sessions. We conclude with lessons learned and identify future developments of the simulation platform.
\end{abstract}

Key Words: Ecopath with Ecosim; Ecospace; marine spatial planning; MSP Challenge; planning support systems; serious gaming; simulation game

\section{INTRODUCTION}

Oceans and seas play a vital role in society, and many countries rely on access to the sea for food and social and economic development (Douvere and Ehler 2009). Marine and coastal ecosystems worldwide are under increasing pressure because of a wide variety of human activities (Kannen 2014, Tamis et al. 2016), and planning and management of marine space is a matter of national and international importance.

Marine or maritime spatial planning (MSP) has developed as a mechanism to cope with the significant challenges that come along with the allocation of human activities and ecological functions to marine space. MSP is seen as a cross-cutting policy tool enabling public authorities and stakeholders to apply a coordinated, integrated, and transboundary approach to marine development (European Commission 2007, Foley et al. 2010, Katsanevakis et al. 2011). In 2014, the European Union (EU) adopted the Maritime Spatial Planning Directive (2014/89/EU). The main purpose of MSP, according to the directive, is to promote sustainable development, to identify the use of maritime space, and to manage spatial uses and conflicts in marine areas (European Commission 2014). However, management of marine space, on short and long time scales, across a wide range of socioeconomic sectors and national and transnational boundaries, under the influence of natural processes and climate change, with their associated uncertainty, is a daunting task for which managers and planners are often ill-prepared (Mayer et al. 2013)

MSP is therefore in dire need of innovative approaches and effective planning support systems by which sectoral planners and stakeholders can assess the current ecological status of marine areas and can also jointly explore the future consequences of planning decisions on the marine environment (Jean et al. 2018). In the last few years, several planning support systems for ecosystem-based MSP have been developed, each one having specific strengths and limitations (Pålsson and Crona 2017, Pınarbaş1 et al. 2017, Menegon et al. 2018). Few of these tools can be qualified as "integrated" in the sense that they link a wide variety of data with simulation models for a range of maritime sectors such as energy (offshore wind farming, energy grid) or shipping. Furthermore, most planning support systems tend to be specialized and scientific, making them useful for desk analysis but less effective in an interactive context for use in stakeholder engagement, transboundary consultation, scenario development, or codesign processes.

In the seminal book Gaming: the Future's Language, Duke (1974) argues that a simulation game or serious game is an excellent communication and learning tool for planning and decision making. Through gameplay, planners and stakeholders experientially understand the dynamic interrelations among various subsystems, the interdependencies among the actors, and the consequences of actions well into the future. Serious games are thus connected to a communicative learning style of planning and planning support (Healey 1996, Muro and Jeffrey 2008, Mayer 2016).

The MSP Challenge simulation platform has been developed to explore these ideas further in the context of ecosystem-based MSP. The MSP Challenge has been designed to help decision makers, stakeholders, and students understand and manage the maritime (blue) economy and marine environment. It uses advanced game technology and aspects of gameplay to engage and facilitate planners and stakeholders in their dialogue and support their learning. To enhance the ability to represent

${ }^{1}$ Ecopath International Initiative (EII), ${ }^{2}$ Centre for Ecological and Evolutionary Synthesis (CEES), Department of Biosciences, University of Oslo, Norway, ${ }^{3}$ COISPA Tecnologia e Ricerca, Bari, Italy, ${ }^{4}$ Scottish Association for Marine Science, Scottish Marine Institute, Oban, Scotland, ${ }^{5}$ European Marine Board, Belgium, ${ }^{6}$ Breda University of Applied Sciences, Breda, The Netherlands, ${ }^{7}$ Rijkswaterstaat, The Netherlands, ${ }^{8}$ Environmental Policy Group, Wageningen University, The Netherlands, ${ }^{9}$ Formerly, Scottish Coastal Forum, Edinburgh, Scotland, ${ }^{10}$ Atkins, Glasgow, Scotland, ${ }^{11}$ Ministry of Infrastructure and Water Management, The Netherlands 
ecological effects of spatial plans (Steenbeek 2018), the simulation platform has been integrated with the ecosystem modeling approach Ecopath with Ecosim (EwE; Christensen and Walters 2004, Heymans et al. 2016). Here, we examine if EwE can be connected to MSP, considering the range of constraints imposed by fast model runs, while still providing cascading ecological feedback. The connection is tested by adapting two published ecological models for use in MSP sessions. We conclude with lessons learned and identify future developments of the simulation platform.

\section{METHODS}

\section{Maritime Spatial Planning Challenge simulation platform}

The MSP Challenge simulation platform integrates best available geographic, maritime, and marine data provided by many proprietary institutions (e.g., Copernicus, EMODnet, HELCOM, IMO) with science-based simulation models for shipping, energy, and ecology. These data and models are linked together in a Unity game-engine based interactive platform (Abspoel et al. 2020). The simulation platform allows anyone, experts as well as nonexperts, to operate it for planning support such as stakeholder engagement, codesign, interactive scenario development, professional learning, and student education. The current platform hosts three editions, for the North Sea, Baltic Sea, and Clyde marine region. Because the platform is built in a highly modular fashion, it can host any sea basin in the world.

Since its launch in 2018, the MSP Challenge simulation platform has been used for many interactive sessions with planners, stakeholders, and students in different parts of the world. In an interactive session or "game", participants take up the role of planner (or stakeholder) in one of the countries in a sea basin. As planners, users have an overview of the entire sea region and can review many different data layers to make an assessment of the current status. They can develop and implement plans for future uses of space in their exclusive economic zone over a period of several decades. They can also consult other countries or develop and implement transboundary plans: shipping routes, wind farms and power grids, or marine protected areas (MPAs). The consequences of planning decisions for energy, shipping, and the marine environment are simulated and visualized in indicators and heat maps at the sea basin level. Digital game technology makes it fun and easy to draw and modify plans, run the simulations, and interact with others. Elements of gameplay such as challenges and objectives, a story line, role-play, and performance feedback can be used to facilitate interactions among the participants in a session.

\section{Ecopath with Ecosim ecosystem modeling}

EwE is the world's most widely used ecosystem modeling approach. Initially conceived to assess the impacts of fisheries on marine food webs (Polovina 1984, Christensen and Walters 2004), the EwE approach is increasingly used to assess the effects of environmental change on marine ecosystems for policy advice (e.g., Christensen et al. 2014, de Mutsert et al. 2017). The first component of the EwE suite is Ecopath, which uses the concept of functional groups and fishing gear types to describe the trophic flows and their exploitation in an ecosystem over a period of typically one year. Ecosim, the time-dynamic module of EwE, uses the mass-balanced Ecopath conditions as a starting point to describe the dynamics within an ecosystem over time, and is used for replicating past ecosystem trends to understand historical ecosystem dynamics and for exploring future scenarios (Christensen and Walters 2004, Heymans et al. 2016). Finally, Ecospace is the spatial-temporal explicit module of EwE. Ecospace represents the modelled area through a grid of equally sized cells in which functional groups and fisheries interact according to a modified version of the Ecosim differential equations (Walters et al. 1999, Christensen et al. 2014).

Ecospace contains a spatially explicit niche model, the habitat foraging capacity model (HFCM), in which the cell suitability is derived from preferences for substrate and/or tolerances to environmental conditions (Christensen et al. 2014). Spatial distributions of fisheries in Ecospace are driven by potential yields vs. the cost of fishing in specific locations. Ecospace can impose fishing limitations on specific gear types through the notions of unsuitable habitat or marine protected areas (Christensen and Walters 2004, Martell et al. 2005). The addition of a dynamic geospatial data exchange framework (Steenbeek et al. 2013) has opened up Ecospace to increased realism (de Mutsert et al. 2017, Peck et al. 2018). More details on the Ecopath approach are provided in Appendix 1.

\section{Connecting Maritime Spatial Planning Challenge and Ecopath with Ecosim}

We designed and created a connection between the existing MSP Challenge simulation platform and the EwE approach to translate the gradual implementation of spatial plans into changes in environmental conditions and fisheries regulations (henceforth called pressures). These pressures were incorporated into the calculations of Ecospace to affect the state of the marine ecosystem components over time and space. Aggregated, spatially explicit Ecospace predictions (henceforth called outcomes) were sent back to the MSP Challenge to disseminate the state of the ecosystem components to session participants (Fig. 1).

Fig. 1. Conceptual linkage of the marine spatial planning (MSP) and Ecopath with Ecosim (EwE) platforms. While game time progresses, players' plans (actions) translate into changes in environment and policy (pressures), which are included in the food web calculations of EwE. Ecological estimates are summarized (outcomes) and sent back to game players.

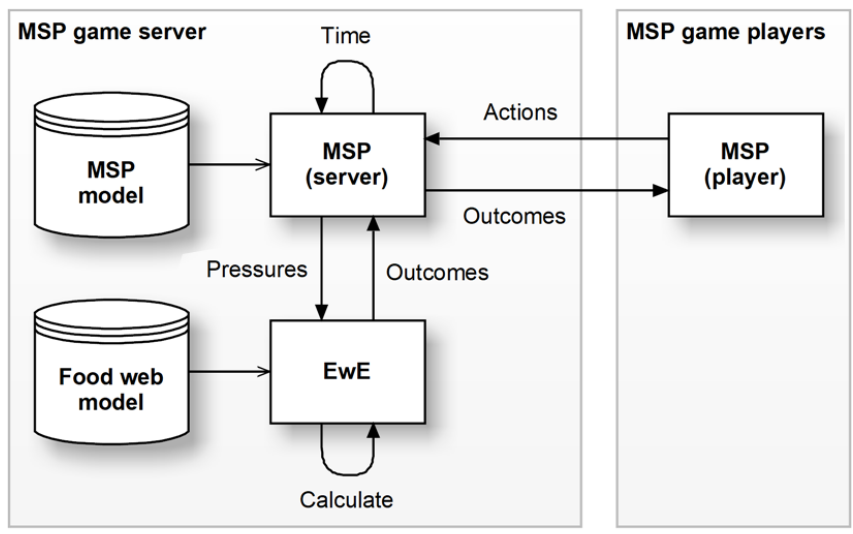

Adjusting an existing EwE model for use in the simulation platform may require changing the structure of a model in terms of functional groups and fleets. It may be required to add species 
and fleets of concern for a particular MSP region. It may also be necessary to reduce the complexity of an existing EwE model to ensure rapid Ecospace execution times during simulation phases. For instance, an EwE model for a MSP Challenge sea basin should contain no more than 30 to 35 functional groups, up to five fishing fleets, and have a spatial grid of no more than 10,000 cells. A protocol for adapting, testing, and validating EwE models to MSP gameplay is available online at https://figshare.com/articles/ EwE model guidelines for MSP game play/5897185/1.

\section{Software framework}

Both the MSP Challenge and the EwE approach are data-driven software systems. Within the bounds of a fixed set of equations and behaviors embedded within the software, these systems are parameterized to represent any ecosystem with its specific challenges and dynamics. We logically connected the MSP Challenge and EwE software systems through a few new software components (Fig. 2). EwEShell encapsulates the EwE modeling logic to receive MSP player-derived pressure maps and aggregates EwE predictions into maps of outcomes. MSPTools is a plug-in to the EwE desktop software that allows EwE modelers to configure how the MSP-derived pressures affect cell suitability and fishing in a EwE model and which EwE predictions need to be aggregated into outcomes. MSPTools also serves to test the behavior of a EwE model as if connected to the actual MSP Challenge session. Lastly, the MSP-EwE Linker integrates EwEShell into the MSP software by converting player actions to pressure maps and by delivering outcomes to the MSP software. The MSPTools plug-in for EwE desktop and its source code are available upon request from http://ecopath.org.

Pressures: impacting the ecological model

Several distinct pressure categories were defined (Table 1):

Table 1. Pressures that reflect environmental disturbance caused by marine spatial planning activities. Each layer expresses the amount of the cell area covered by a pressure, per cell, across the game area.

\begin{tabular}{llll}
\hline \hline Pressure & Description & Format & $\begin{array}{l}\text { Implica- } \\
\text { tion }\end{array}$ \\
\hline Noise & $\begin{array}{l}\text { Amount of anthropogenic low-frequency } \\
\text { noise in a cell }\end{array}$ & Grid & - \\
Bottom & $\begin{array}{l}\text { Amount of cell bottom area that is } \\
\text { disturbed through anthropogenic } \\
\text { disturbance }\end{array}$ & Grid & - \\
& $\begin{array}{l}\text { activities such as construction, } \\
\text { sedimentation, excavation, etc. }\end{array}$ & \\
Surface & $\begin{array}{l}\text { Amount of cell surface area that is } \\
\text { disturbed through anthropogenic } \\
\text { disturbance }\end{array}$ & Grid & - \\
& $\begin{array}{l}\text { activities such as shipping, construction, } \\
\text { etc. }\end{array}$ & & \\
Artificial & $\begin{array}{l}\text { Amount of cell area covered by artificial } \\
\text { habitat } \\
\text { substrate }\end{array}$ & Grid & Protection \\
Protection & $\begin{array}{l}\text { Amount of cell area closed to fishing, per } \\
\text { fishing fleet; each fishing fleet in a marine } \\
\text { spatial planning game will have its own } \\
\text { protection layer }\end{array}$ & Grid & - \\
Scalar to initial fishing pressure, per fleet & Single & - \\
Fishing & & &
\end{tabular}

Fig. 2. An overview of software components needed to connect the Ecopath with Ecosim (EwE) computational core to the marine spatial planning (MSP) challenge. EwE shell is the central software library that encapsulates the EwE modeling logic to receive MSP player-derived pressure layers and to deliver outcome layers back to the MSP software system. MSP tools is a plug-in to the EwE desktop software that allows EwE modelers to design the connectivity between a specific MSP scenario and a EwE model, and to test the behavior of this EwE model as if connected to the actual MSP game. MEL, the MSP-EwE Linker, is a software library that integrates EwE shell into the MSP game engine by converting MSP player actions to pressure maps for consumption by the EwE shell, and by delivering ecological outcomes to the MSP Challenge game.

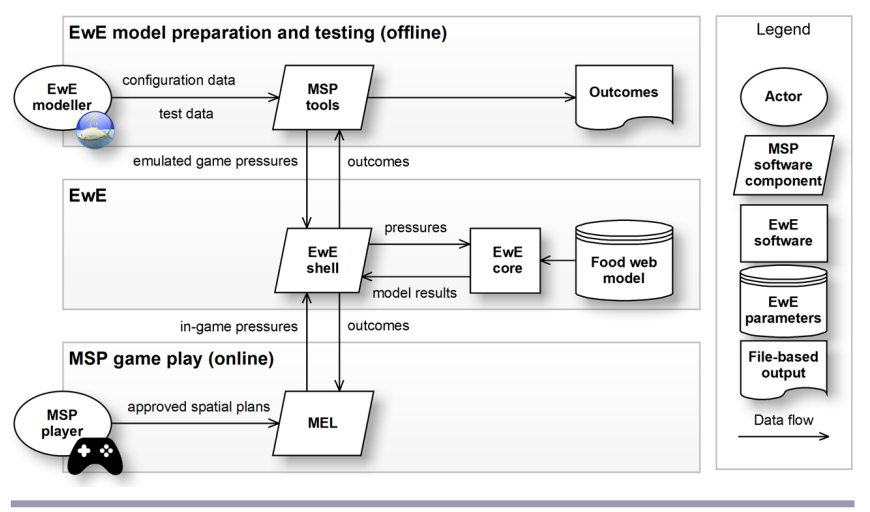

- "Noise" is the spatial distribution and intensity of lowfrequency noise resulting from shipping, construction, etc. The noise map layer acts as an environmental driver layer in the Ecospace HCFM and affects per-cell foraging suitability for functional groups sensitive to low-frequency noise.

- "Surface disturbance" and "bottom disturbance" are the spatial distribution and intensity of physical disturbance at the surface and the bottom, respectively. This pressure includes the presence of temporary and transient structures and vehicles, turbidity due to anthropogenic activity, some forms of pollution, etc. The disturbance map layers act as environmental driver layers in the Ecospace HFCM and affect per-cell foraging suitability for functional groups sensitive to these disturbances.

- "Artificial substrate" is the spatial distribution and intensity of artificial structures that provide shelter and/or habitat to sensitive functional groups. This layer acts as an additional habitat in Ecospace to increase habitat-derived cell suitability in the Ecospace HCFM.

- "Protection" is the spatial distribution of locations where fishing is impossible due to the presence of other activities or prohibited through fisheries restrictions. This per-fleet map layer acts as a MPA layer in Ecospace, blocking fishing effort for all sensitive fishing gears in cells where MSP activities that generate this pressure are present. 
Fig. 3. Schematic overview showing how spatial plans (actions), in vector format, are converted to pressure grids, in raster format. This example shows how oil platforms, ferry and shipping lines, wind park construction, and dredging contribute to the noise pressure grid via conversion factors unique to each type of action.

\section{Placement of spatial plans (vector)}
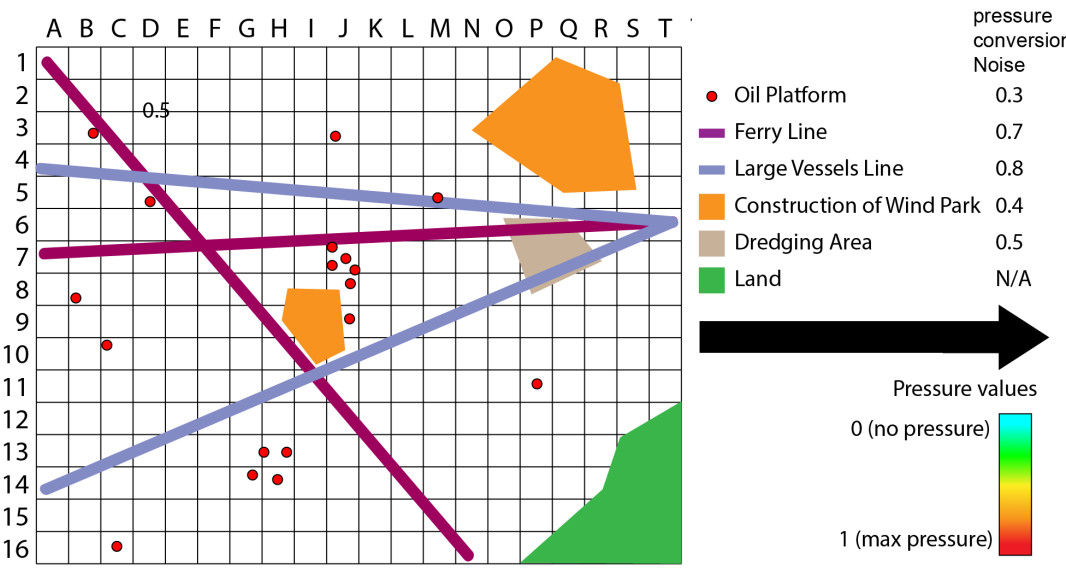

\section{Pressure map of noise (raster)}

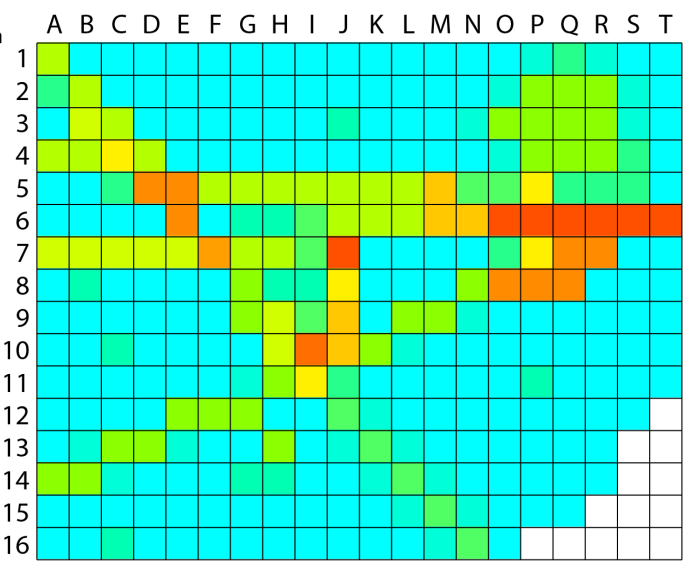

- "Fishing intensity" is a scalar pressure to increase or decrease the nominal amount of fishing across the game area.

During simulation phases, the MSP Challenge software converts spatial plans created by players into pressure maps using an action-pressure conversion matrix, as follows (Fig 3.):

- Spatial plans, which are entered as points (e.g., anchorages, oil and gas platforms) and lines (e.g., shipping routes, cables, pipelines, etc.), are spatially expanded to their area of impact using impact factors, expressed in the action-pressure conversion matrix as a ratio of Ecospace cell size. The zone width may be multiplied by the intensity of the spatial plan where applicable (e.g., shipping intensity). The zone-to-cell surface overlap is then calculated as a measure of spatially explicit pressure intensity on a value range from zero (no pressure) to one (maximum pressure).

- The cell area overlap of spatial plans, which are entered as polygons (e.g., dredging sites, marine protected areas, harbors, wind farms, etc.), is directly calculated and multiplied by the impact amount stated in the actionpressure matrix and intensity of the spatial plan, where applicable.

- Total pressures from point, line, and polygon features are added per cell and range from zero (no pressure) to one (maximum pressure).

Ecospace directly integrates the pressure grids into designated maps of environmental drivers, habitats, and protection, and directly incorporates the per-fleet fishing effort multiplier, to affect ecosystem dynamics.

Outcomes: summarizing ecological changes in the Marine Spatial Planning software

Outcomes are spatially explicit aggregations of Ecospace predictions. The complex results of food web dynamics are condensed to provide MSP session participants with key ecological results and indicators. Outcomes can consist of four types of Ecospace predictions: group biomass, group catch, fleet effort, and biodiversity indicators. The data in the outcome maps are reflected in the MSP software on a fixed color gradient that represents one order of magnitude deviation from Ecopath baseline values. This relatively simple display system facilitates game participants to perceive drastic (local) changes in ecosystem functioning on a uniform scale across all outcomes.

\section{Case studies}

We integrated two existing published and previously fitted EwE models into the MSP Challenge simulation platform: one representing the North Sea and the other the Firth of Clyde (west coast of Scotland). Because the two systems differ greatly in spatial scale, species diversity, spatial homogeneity, and planning challenges, we included both case studies here to provide a broad overview of model integration challenges as a guideline for similar future exercises.

\section{Case study 1: North Sea} Background

This case study concerns integrating a model for the entire North Sea (Mackinson and Daskalov 2007, Romagnoni et al. 2015) for the project "A North Sea Perspective on Shipping, Energy, and Environmental Aspects in Maritime Spatial Planning (NorthSEE)" (https://northsearegion.eu/northsee).

The North Sea is a relative shallow sea of approximately 570,000 $\mathrm{km}^{2}$ and is one of the busiest seas in the world, with intense shipping movement and fisheries targeting mainly cod (Gadus morhua), haddock (Melanogrammus aeglefinus), herring (Clupea harengus), and saithe (pollock, Pollachius virens). Oil and gas extraction has been an important economic sector since the 1960s, especially for the UK, Norway, and the Netherlands, and more recently, aquaculture has been developed in the area. Countries bordering the North Sea are planning to install up to $62 \mathrm{GW}$ of offshore wind energy by 2030 to meet the Paris Agreement on $\mathrm{CO}_{2}$ emissions reductions. Hence, the growing need to 
Table 2. Basic inputs for the condensed and balanced marine spatial planning challenge North Sea Ecopath model. Parameters definitions: $\mathrm{TL}=$ trophic level, $\mathrm{B}=$ biomass (tonne $/ \mathrm{km} \& \sup 2), \mathrm{P} / \mathrm{B}=$ production $/$ biomass $($ per $\mathrm{yr}$ ), $\mathrm{Q} / \mathrm{B}=$ consumption $/ \mathrm{biomass}($ per $\mathrm{yr}), \mathrm{EE}=$ ecotrophic efficiency, and $\mathrm{P} / \mathrm{Q}=$ production/consumption. Parameters estimated by the model are underlined. Functional groups that include more than one of the groups from the original North Sea model are in bold font and their components are in italics.

\begin{tabular}{|c|c|c|c|c|c|c|c|c|}
\hline \multirow[b]{2}{*}{$\begin{array}{l}\text { Group } \\
\text { num- } \\
\text { ber }\end{array}$} & \multirow[b]{2}{*}{$\begin{array}{l}\text { Marine spatial planning } \\
\text { functional grouping }\end{array}$} & \multirow[b]{2}{*}{ Condensed groups } & \multicolumn{6}{|c|}{ Parameter } \\
\hline & & & $\mathrm{TL}$ & B & $\mathrm{P} / \mathrm{B}$ & $\mathrm{Q} / \mathrm{B}$ & $\mathrm{EE}$ & $\mathrm{P} / \mathrm{Q}$ \\
\hline \multirow[t]{3}{*}{1} & Cetacean & & 4.278 & 0.084 & 0.020 & 11.464 & $\underline{0.396}$ & $\underline{0.002}$ \\
\hline & & Baleen whales & 4.444 & 0.067 & 0.02 & 9.900 & $\overline{0.000}$ & $\overline{0.002}$ \\
\hline & & Toothed whales & 4.644 & 0.017 & 0.02 & 17.630 & 0.000 & 0.001 \\
\hline 2 & Seal & & 4.886 & 0.008 & 0.090 & 26.842 & $\underline{0.000}$ & $\underline{0.003}$ \\
\hline 3 & Diving seabirds & & 4.084 & 0.004 & 0.450 & 86.970 & $\underline{0.000}$ & $\underline{0.005}$ \\
\hline 4 & Surface-feeding seabirds & & 3.139 & 0.002 & 0.237 & 77.280 & $\overline{0.000}$ & $\overline{0.003}$ \\
\hline \multirow[t]{3}{*}{5} & Cod & & 4.668 & 0.130 & 1.190 & 2.170 & $\underline{0.916}$ & $\underline{0.548}$ \\
\hline & & Cod (juvenile 0-2) & 4.306 & 0.100 & & 4.967 & $\overline{0.989}$ & $\overline{0.360}$ \\
\hline & & Cod (adult) & 4.806 & 0.130 & & 2.170 & 0.911 & 0.548 \\
\hline \multirow[t]{7}{*}{6} & Commercial gadoids & & 4.225 & 0.760 & 0.927 & 4.455 & $\underline{0.963}$ & $\underline{0.208}$ \\
\hline & & Whiting (juvenile 0-1) & 4.255 & 0.027 & & 17.402 & $\overline{0.917}$ & 0.136 \\
\hline & & Whiting (adult) & 4.336 & 0.430 & & 5.460 & 0.981 & 0.163 \\
\hline & & Haddock (juvenile 0-1) & 4.057 & 0.008 & & 7.685 & 0.883 & 0.260 \\
\hline & & Haddock (adult) & 4.265 & 0.120 & & 2.350 & 0.824 & 0.485 \\
\hline & & Saithe (juvenile 0-3) & 4.022 & 0.116 & & 8.511 & 0.904 & 0.117 \\
\hline & & Saithe (adult) & 4.337 & 0.210 & & 3.600 & 0.716 & 0.244 \\
\hline \multirow[t]{9}{*}{7} & Demersal predators & & 4.534 & 0.269 & 0.658 & 2.076 & $\underline{0.647}$ & $\underline{0.317}$ \\
\hline & & Juvenile sharks & 4.281 & 0.001 & 0.500 & 2.500 & 0.194 & 0.200 \\
\hline & & Spurdog & 4.748 & 0.130 & 0.480 & 2.000 & 0.229 & 0.240 \\
\hline & & Large piscivorous sharks & 4.918 & 0.001 & 0.440 & 1.600 & 0.619 & 0.275 \\
\hline & & Small sharks & 4.334 & 0.002 & 0.510 & 2.960 & 0.337 & 0.172 \\
\hline & & Hake & 4.901 & 0.014 & 0.820 & 2.200 & 0.681 & 0.373 \\
\hline & & Other gadoids (large) & $\underline{4.515}$ & 0.065 & 1.000 & 2.500 & 0.950 & 0.400 \\
\hline & & Monkfish & 4.823 & 0.042 & 0.700 & 1.700 & 0.853 & 0.412 \\
\hline & & Catfish (Wolf-fish) & 4.272 & 0.014 & 0.480 & 1.700 & 0.802 & 0.282 \\
\hline \multirow[t]{3}{*}{8} & Pelagic small gadoids & & 3.440 & 1.540 & 2.245 & 5.649 & $\underline{0.794}$ & $\underline{0.397}$ \\
\hline & & Blue whiting & 4.094 & 0.230 & 2.5 & 9.060 & 0.321 & 0.276 \\
\hline & & Norway pout & 3.586 & 1.310 & 2.2 & 5.050 & 0.980 & 0.436 \\
\hline \multirow[t]{3}{*}{9} & Herring & & 3.274 & 2.823 & $\underline{0.504}$ & 4.705 & 0.990 & $\underline{0.107}$ \\
\hline & & Herring (juvenile 0-1) & 3.420 & 0.143 & & 11.537 & 0.888 & $\overline{0.114}$ \\
\hline & & Herring (adult) & 3.436 & 2.680 & & 4.340 & 0.567 & 0.184 \\
\hline \multirow[t]{3}{*}{10} & Sandeel and sprat & & 3.319 & 2.429 & 2.280 & 5.250 & $\underline{0.896}$ & $\underline{0.434}$ \\
\hline & & Sandeels & 3.345 & 1.850 & 2.28 & 5.240 & $\overline{0.991}$ & $\overline{0.435}$ \\
\hline & & Sprat & 2.959 & 0.579 & 2.28 & 5.280 & 0.839 & 0.432 \\
\hline 11 & Mackerel & & 3.745 & 0.750 & 0.600 & 1.730 & $\underline{0.772}$ & $\underline{0.347}$ \\
\hline \multirow[t]{3}{*}{12} & Small pelagic fish & & 3.763 & 0.779 & 1.015 & 3.747 & $\overline{0.311}$ & $\overline{0.271}$ \\
\hline & & $\begin{array}{l}\text { Miscellaneous filter-feeding } \\
\text { pelagic fish }\end{array}$ & $\underline{3.432}$ & 0.029 & 4 & 10.190 & $\overline{0.990}$ & $\overline{0.393}$ \\
\hline & & Horse mackerel & 4.277 & 0.750 & 0.9 & 3.500 & 0.227 & 0.257 \\
\hline \multirow[t]{11}{*}{13} & Flatfish & & 3.951 & 4.431 & 0.734 & 3.818 & $\underline{0.384}$ & $\underline{0.192}$ \\
\hline & & Plaice & 3.982 & 0.580 & 0.85 & 3.420 & 0.850 & 0.249 \\
\hline & & $D a b$ & 4.001 & 2.800 & 0.672 & 4.000 & 0.222 & 0.168 \\
\hline & & Long-rough dab & 4.178 & 0.350 & 0.7 & 4.000 & 0.489 & 0.175 \\
\hline & & Flounder & 4.377 & 0.250 & 1.1 & 3.200 & 0.261 & 0.344 \\
\hline & & Sole & 3.998 & 0.135 & 0.8 & 3.100 & 0.882 & 0.258 \\
\hline & & Lemon sole & 3.938 & 0.140 & 0.864 & 4.320 & 0.502 & 0.200 \\
\hline & & Witch & 4.046 & 0.082 & 0.9 & 3.000 & 0.396 & 0.300 \\
\hline & & Turbot & 4.535 & 0.027 & 0.86 & 2.100 & 0.583 & 0.410 \\
\hline & & Megrim & 4.454 & 0.034 & 0.72 & 3.100 & 0.249 & 0.232 \\
\hline & & Halibut & 4.513 & 0.033 & 0.16 & 3.140 & 0.278 & 0.051 \\
\hline \multirow[t]{5}{*}{14} & Large demersal fish & & 4.254 & 0.799 & 0.647 & 1.782 & $\underline{0.086}$ & $\underline{0.363}$ \\
\hline & & Juvenile rays & 4.231 & 0.268 & 0.66 & 1.700 & 0.006 & 0.388 \\
\hline & & Starry ray + others & 4.428 & 0.390 & 0.66 & 1.700 & 0.050 & 0.388 \\
\hline & & Thornback and spotted ray & 4.495 & 0.066 & 0.78 & 2.300 & 0.217 & 0.339 \\
\hline & & Skate + cuckoo ray & 4.426 & 0.050 & 0.35 & 1.800 & 0.386 & 0.194 \\
\hline
\end{tabular}




\begin{tabular}{|c|c|c|c|c|c|c|c|c|}
\hline & & Large demersal fish & 4.208 & 0.025 & 0.55 & 2.540 & 0.900 & 0.217 \\
\hline \multirow[t]{5}{*}{15} & Small demersal fish & & 4.045 & 0.850 & 1.419 & 3.862 & 0.860 & 0.367 \\
\hline & & Other gadoids (small) & $\underline{3.813}$ & 0.280 & 1.8 & 4.000 & 0.990 & 0.450 \\
\hline & & Gurnards & $\overline{4.440}$ & 0.180 & 0.82 & 3.200 & 0.264 & 0.256 \\
\hline & & Dragonets & 3.974 & 0.045 & 1.44 & 6.900 & 0.955 & 0.209 \\
\hline & & Small demersal fish & 4.227 & 0.345 & 1.42 & 3.700 & 0.990 & 0.384 \\
\hline 16 & Squid and cuttlefish & & 3.608 & 0.060 & 4.500 & 15.000 & $\underline{0.825}$ & $\underline{0.300}$ \\
\hline \multirow[t]{4}{*}{17} & Zooplankton & & 2.261 & 19.213 & 8.327 & 27.053 & $\overline{0.620}$ & 0.308 \\
\hline & & Carnivorous zooplankton & 3.228 & 3.147 & 4 & 12.500 & 0.990 & 0.320 \\
\hline & & $\begin{array}{l}\text { Herbivorous and omnivorous } \\
\text { zooplankton (copepods) }\end{array}$ & 2.057 & 16.000 & 9.2 & 30.000 & 0.384 & 0.307 \\
\hline & & Gelatinous zooplankton & 3.574 & 0.066 & 2.9 & 6.444 & 0.793 & 0.450 \\
\hline 18 & Large crabs & & 3.680 & 1.200 & $\underline{0.550}$ & 2.750 & 0.961 & $\underline{0.200}$ \\
\hline \multirow[t]{5}{*}{19} & Large benthic invertebrates & & 2.991 & 215.054 & $\overline{0.779}$ & 2.828 & $\overline{0.412}$ & 0.275 \\
\hline & & Nephrops & 3.503 & 0.980 & $\underline{0.37}$ & 1.850 & $\overline{0.988}$ & 0.200 \\
\hline & & Epifaunal macrobenthos & 3.310 & 78.000 & 0.3883938 & 1.942 & 0.433 & 0.200 \\
\hline & & Infaunal macrobenthos & 2.870 & 136.000 & 1 & 3.333 & 0.275 & 0.300 \\
\hline & & Shrimp & 3.053 & 0.074 & $\overline{11}$ & 22.000 & 0.997 & 0.500 \\
\hline \multirow[t]{5}{*}{20} & Small benthic invertebrates & & 2.851 & 288.821 & 1.166 & 4.088 & 0.933 & $\underline{0.285}$ \\
\hline & & Small mobile epifauna & 2.893 & 30.000 & $\underline{1.36}$ & 3.886 & $\overline{0.982}$ & 0.350 \\
\hline & & Small infauna & 2.954 & 150.000 & 0.9 & 3.000 & 0.869 & 0.300 \\
\hline & & Sessile epifauna & 2.797 & 105.000 & $\underline{0.26}$ & 1.300 & 0.028 & 0.200 \\
\hline & & Meiofauna & 3.030 & 3.821 & 35 & 125.000 & 0.990 & 0.280 \\
\hline \multirow[t]{3}{*}{21} & $\begin{array}{l}\text { Microflora (including } \\
\text { bacteria, protozoa) }\end{array}$ & & $\overline{2.143}$ & 1.545 & 1175.786 & 2351.573 & $\underline{0.729}$ & 0.500 \\
\hline & & Benthic microflora & 2.238 & 0.105 & 9470 & 18940.000 & 0.950 & 0.500 \\
\hline & & Planktonic microflora & 2.139 & 1.440 & 571 & 1142.000 & 0.725 & 0.500 \\
\hline 22 & Phytoplankton & & 1.000 & 7.500 & $28 \overline{6.6} 67$ & 0.000 & $\underline{0.208}$ & \\
\hline \multirow[t]{4}{*}{23} & Detritus and discards & & 1.000 & 25.000 & & & 0.931 & \\
\hline & & $\begin{array}{l}\text { Detritus: dissolved organic matter, } \\
\text { water column }\end{array}$ & 1.000 & 25.000 & & & $\overline{0.914}$ & \\
\hline & & $\begin{array}{l}\text { Detritus: particulate organic } \\
\text { matter, sediment }\end{array}$ & 1.000 & 25.000 & & & 0.940 & \\
\hline & & Discards & 1.000 & 0.000 & & & 0.993 & \\
\hline
\end{tabular}

accommodate offshore wind park construction will be one of the main drivers for future development, resulting in spatial claims and possible conflicts with other uses. Increasing development in the North Sea has cross-border impacts, which require the involved organizations to cooperate more efficiently regarding the establishment of coherent international networks of MPAs, dealing with cumulative ecological impacts, multiple use of space (for example, offshore wind energy coinciding with aquaculture or other forms of energy), and land-sea interactions, among other factors. Because national policies leave room for different interpretations, countries do not always follow comparable methods and approaches for development within their areas of jurisdiction.

The NorthSEE project aimed to achieve greater coherence between MSP processes and maritime spatial plans, as well as furthering sustainable development in the North Sea through MSP. Several national MSP authorities and knowledge institutions worked together to develop and share knowledge on key economic sectors and future developments, transnational planning, and institutional developments. As part of the NorthSEE project, the North Sea area was captured in an updated version of the MSP Challenge simulation platform to engage and teach planners and sectoral stakeholders about planning challenges in the North Sea.

\section{Ecopath with Ecosim model}

We based this case study on the original model for the North Sea (Mackinson and Daskalov 2007), updated with more recent data
(ICES 2015). This model was too computationally demanding for integration into MSP simulations and was thus reduced in complexity. Charismatic groups (e.g., seals, cetaceans), commercially important groups (e.g., cod, herring, sandeel [Ammodytes spp.]), and groups subject to anthropogenic impacts or legal protection at the international level and thus in need of monitoring (e.g., seabirds, benthic invertebrates) were retained in the model because they were essential to MSP interests. Other groups were aggregated to reduce the computational cost of running the model (Table 2) based on ecological, taxonomic, or other considerations such as similarities in spatial distribution or catch dynamics. Original fleets were aggregated based on similarities in catches and economic characteristics. Three main fleets were considered relevant for MSP game player control (bottom trawl, industrial and pelagic trawl, and drift- and fixednet fleets), whereas others (gears using hooks, dredges, pots, or other gear) were kept constant in the model to retain ecosystem dynamics (Table 3 ).

The resulting Ecopath model was balanced and calibrated according to best practices (Heymans et al. 2016). Temporal model predictions in Ecosim were calibrated using time series of biomass, catch, total mortality, and fishing mortality. Using the automated stepwise fitting plugin (Scott et al. 2016), model fit was improved via the estimation of predator vulnerabilities. Model fit was statistically measured using the Akaike information criterion for small sample sizes (AICc; Burnham and Anderson 2002). In total, 31 vulnerabilities were estimated, reducing the sum of squared deviations from 512.3 to 391.5 and AICc from -305.4 to -443.4 . 
Table 3. Fishing fleet structure, landings, and discards for the condensed marine spatial planning challenge North Sea Ecopath model. Fleets that include more than one of the fleets from the original North Sea model are in bold font and their components are in italics.

\begin{tabular}{|c|c|c|c|c|}
\hline Fleet number & Fishing fleet type & Condensed fleets & Landings (tonne $/ \mathrm{km}^{2}$ ) & Discards (tonne $/ \mathrm{km}^{2}$ ) \\
\hline \multirow[t]{5}{*}{1} & Bottom trawl & & 1.303 & 0.367 \\
\hline & & $\begin{array}{l}\text { Demersal trawl }+ \text { dem } \\
\text { seine }\end{array}$ & 0.782 & 0.151 \\
\hline & & Beam trawl & 0.406 & 0.177 \\
\hline & & Nephrops trawl & 0.090 & 0.076 \\
\hline & & Shrimp trawlers & 0.074 & 0.041 \\
\hline \multirow[t]{3}{*}{2} & $\begin{array}{l}\text { Industrial and pelagic } \\
\text { trawl }\end{array}$ & & 2.511 & 0.031 \\
\hline & & Industrial trawl & 1.256 & 0.008 \\
\hline & & Pelagic trawl & 1.255 & 0.023 \\
\hline 3 & Drift and fixed nets & & 0.024 & 0.001 \\
\hline 4 & Gears using hooks & & 0.002 & 0.000 \\
\hline 5 & Dredges & & 0.586 & 0.000 \\
\hline 6 & Pots & & 0.007 & 0.000 \\
\hline 7 & Other & & 0.156 & 0.020 \\
\hline
\end{tabular}

The Ecospace model area was divided into a grid of 85 columns and 144 rows at $10 \times 10 \mathrm{~km}$ cells. The spatial model included five habitat types based on depth and ecological relevance following Romagnoni et al. (2015). An additional "artificial substrate" habitat was included to receive the corresponding pressure from the MSP game. Relevant groups such as benthic invertebrates were assigned preferences to this new habitat based on existing literature (Baine 2001, Perkol-Finkel and Benayahu 2005). Spatial distributions were driven by habitat preference and by the functional responses to environmental conditions for selected groups through the Ecospace HFCM. Functional responses to distance from shore were applied to seals and seabirds (Karpouzi et al. 2007, Jones et al. 2013). Additionally, known seabird forage and migration habitat areas were included to define base distributions.

Little information was available for species-specific functional responses to changing intensities of anthropogenic pressures; however, there is abundant literature to support that these pressures can detrimentally affect marine communities. Anthropogenic noise has been found to affect the foraging and resting behaviours of seals (Mikkelsen et al. 2019) and seabirds (Buxton et al. 2017) and has been linked to fatal stranding (Forney et al. 2017), hearing damage (Ketten 2012), disrupted foraging and reproductive behavior (Gomez et al. 2016), and changes to the distributions (Graham et al. 2017) of cetaceans. The presence and physical disturbance caused by boats and recreational activities on the water's surface can have short-term effects on marine mammal behavior (Lusseau 2003), lead to displacement (Machernis et al. 2018), and increase the risk of physical harm via ship strikes (Redfern et al. 2013). Finally, activities that result in bottom disturbance, such as the installation and operation of renewable energy or the extraction of aggregates, can lead to the destruction of benthic habitats (Gill 2005, Foden et al. 2010). Many benthic invertebrates are sensitive to habitat disturbance and often suffer high mortality leading to reduced biomass, production, and species richness (Hinz et al. 2009).

Simple linear functional responses were used to link functional groups to specific MSP pressures in the Ecospace HFCM (Table
4) using three response curves: low negative, high negative, and positive (Fig. 4). As the intensity of a pressure increased, the habitat foraging capacity multiplier for functional groups with low negative responses would decline to 0.5 at maximum pressure intensity. For functional groups with high negative responses, the habitat foraging capacity at maximum pressure intensity declined to zero, making it impossible for affected functional groups to feed within the corresponding Ecospace cell.

Table 4. Functional responses by pressure (noise, surface disturbance, bottom disturbance) as assigned for each group in the ecosystem, at initial settings.

\begin{tabular}{|c|c|c|c|c|}
\hline \multirow[b]{2}{*}{$\begin{array}{l}\text { Group } \\
\text { number }\end{array}$} & \multirow[b]{2}{*}{ Group name } & \multicolumn{3}{|c|}{ Pressure } \\
\hline & & Noise & $\begin{array}{c}\text { Surface } \\
\text { disturbance }\end{array}$ & $\begin{array}{c}\text { Bottom } \\
\text { disturbance }\end{array}$ \\
\hline$\overline{1}$ & Cetacean & High & Low & \\
\hline 2 & Seal & Low & Low & \\
\hline 3 & Windfarm-avoiding seabirds & Low & Positive & \\
\hline 4 & Windfarm-indifferent seabirds & Low & Positive & \\
\hline 5 & Cod & & & \\
\hline 6 & Commercial gadoids & & & \\
\hline 7 & Demersal predators & & & \\
\hline 8 & Pelagic small gadoids & & & \\
\hline 9 & Herring & & & \\
\hline 10 & Sandeel and sprat & & & \\
\hline 11 & Mackerel & & & \\
\hline 12 & Small pelagic fish & & & \\
\hline 13 & Flatfish & & & \\
\hline 14 & Large demersal fish & & & \\
\hline 15 & Small demersal fish & & & \\
\hline 16 & Squid and cuttlefish & & & \\
\hline 17 & Zooplankton & & & \\
\hline 18 & Large crabs & & & High \\
\hline 19 & Large benthic invertebrates & & & High \\
\hline 20 & Small benthic invertebrates & & & High \\
\hline 21 & $\begin{array}{l}\text { Microflora (including bacteria, } \\
\text { protozoa) }\end{array}$ & & & \\
\hline 22 & Phytoplankton & & & \\
\hline 23 & Detritus and discards & & & \\
\hline
\end{tabular}


Table 5. Outcomes delivered by Ecopath with Ecosim the marine spatial planning challenge game for the North Sea Ecospace model, covering 11 biomass summaries, three catch summaries, and two ecological indicators. The outcomes labelled as benthic invertebrates and demersal fish contain aggregations of functional groups. The large fish indicator (Engelhard et al. 2015) is a per-cell result of the sum of biomass of cod and commercial gadoids divided by the sum of biomass of all fish. Ecospace in Ecopath with Ecosim release 6.5 and newer versions calculate the Shannon diversity indicator following Shannon (1948).

\begin{tabular}{|c|c|c|c|}
\hline Category & Outcome name & $\begin{array}{l}\text { Number of } \\
\text { components }\end{array}$ & Components \\
\hline \multirow{11}{*}{$\begin{array}{l}\text { Biomass } \\
\text { (group) }\end{array}$} & Benthic invertebrates & 3 & Large crabs, large benthic invertebrates, small benthic invertebrates \\
\hline & Cetacean & 1 & Cetacean \\
\hline & Cod & 1 & Cod \\
\hline & Demersal fish & 2 & Commercial gadoids, demersal predators \\
\hline & Flatfish & 1 & Flatfish \\
\hline & Herring & 1 & Herring \\
\hline & Mackerel & 1 & Mackerel \\
\hline & Sandeel & 1 & Sandeel and sprat \\
\hline & Seal & 1 & Seal \\
\hline & Windfarm-avoiding seabird & 1 & Windfarm-avoiding seabirds \\
\hline & Windfarm-indifferent seabird & 1 & Windfarm-indifferent seabirds \\
\hline Catch & Bottom trawl & 1 & Bottom trawl (otter, beam, seine) \\
\hline \multirow[t]{2}{*}{ (fleet) } & Drift and fixed nets & 1 & Drift and fixed nets \\
\hline & Pelagic and industrial trawl & 1 & Industrial and pelagic trawl \\
\hline \multirow[t]{2}{*}{$\begin{array}{l}\text { Indicator } \\
\text { (group) }\end{array}$} & Large fish indicator & 11 & $\begin{array}{l}\text { Cod, commercial gadoids, demersal predators, pelagic small gadoids, herring, sandeel and } \\
\text { sprat, mackerel, small pelagic fish, flatfish, large demersal fish, small demersal fish }\end{array}$ \\
\hline & Shannon diversity indicator & 1 & - \\
\hline
\end{tabular}

Fig. 4. Functional responses for low negative, high negative, and positive impacts used in the final version of the North Sea model.

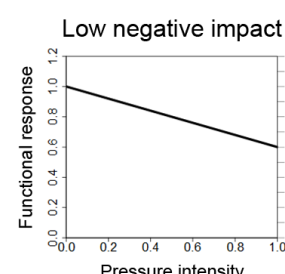

Pressure intensity

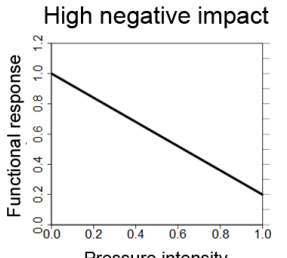

Pressure intensity

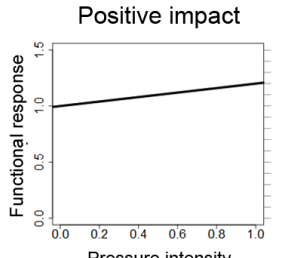

Pressure intensity
The choice and configuration of outcomes delivered back to the MSP Challenge North Sea edition were determined in close collaboration with the NorthSEE project, and incorporated iconic, commercial, or ecologically important species, fishing activities, and two ecological indicators (Table 5).

\section{Testing}

The North Sea EwE model was calibrated to approximate species distributions and intensities of the original model. Based on literature, species most sensitive to one or more MSP pressures were configured accordingly. Model performance was then tested and validated through an incremental introduction of MSP startup pressures (e.g., pressures caused by MSP activities present in the model at the start of a game) following the aforementioned protocol.

The model was integrated in the MSP Challenge North Sea edition and tested during a full-day session with NorthSEE project participants. The model was adjusted to incorporate test session feedback and was formally delivered at the NorthSEE project closure meeting. The assemblage of the model with focus on reparameterization, assumptions, and pressure testing is detailed by Romagnoni (2019).

Case study 2: Firth of Clyde

Background

The second case study pertains to the integration of a model for the west coast of Scotland (Haggan and Pitcher 2005, Alexander et al. 2015, Serpetti et al. 2017) into a MSP Challenge Clyde Marine Region edition for the project "Supporting Implementation of Maritime Spatial Planning in the Celtic Seas (SimCELT)" (http://www.simcelt.eu/).

The River Clyde and its wider estuary, or firth, is one of Scotland's most iconic and economically important waterbodies, with a highly indented coastline of $>1200 \mathrm{~km}$ with numerous islands. Under the EU-funded SIMCelt project (2015-2018), a case study was proposed for the Clyde Marine Region that examined the challenges of undertaking marine planning across administrative borders. In particular, it considered innovative mechanisms for stakeholder engagement and used the MSP Challenge approach (a board game, not discussed here, and the simulation platform) to test whether a better understanding of MSP and the complexity of marine ecosystems could be achieved. Because the MSP Challenge simulation platform was initially developed for extensive sea areas with high diversity and intense use such as the North Sea, adapting the game to the Clyde Marine Region was a challenge because of its relatively small size coupled with diverse and overlapping uses. The Clyde Marine Region is intensively used for recreation, commercial shipping, lifeline ferry services, military, and industrial purposes. There is currently no renewable energy production in the Clyde Marine Region because conditions are not favorable. The fishing industry in the Clyde Marine Region focuses on five fleets: demersal trawl, scallop fleet, Nephrops fleet, pots and creel, and seine. There are also two no- 
Table 6. Basic estimates for the condensed and balanced marine spatial planning challenge Clyde Sea Ecopath model. Parameters definitions: $\mathrm{TL}=$ trophic level, $\mathrm{B}=$ biomass $\left(\right.$ tonne $\left./ \mathrm{km}^{2}\right), \mathrm{P} / \mathrm{B}=$ production $/$ biomass $($ per $\mathrm{yr}), \mathrm{Q} / \mathrm{B}=$ consumption $/$ biomass $($ per $\mathrm{yr})$, $\mathrm{EE}=$ ecotrophic efficiency, and $\mathrm{P} / \mathrm{Q}=$ production/consumption. Parameters estimated by the model are underlined. Functional groups that include more than one of the groups from the uncondensed Clyde Sea model are in bold font and their components are in italics.

\begin{tabular}{|c|c|c|c|c|c|c|c|c|}
\hline \multirow[b]{2}{*}{$\begin{array}{l}\text { Group } \\
\text { number }\end{array}$} & \multirow[b]{2}{*}{$\begin{array}{l}\text { Marine spatial planning } \\
\text { functional groupings }\end{array}$} & \multirow[b]{2}{*}{ Condensed groups } & \multicolumn{6}{|c|}{ Parameter } \\
\hline & & & $\mathrm{TL}$ & B & $\mathrm{P} / \mathrm{B}$ & $\mathrm{Q} / \mathrm{B}$ & $\mathrm{EE}$ & $\mathrm{P} / \mathrm{Q}$ \\
\hline 1 & Seals & & 4.364 & 0.047 & 0.111 & 12.000 & $\underline{0.000}$ & $\underline{0.009}$ \\
\hline 2 & Cetaceans & & 4.074 & 0.126 & 0.090 & 14.000 & $\underline{0.000}$ & $\underline{0.006}$ \\
\hline 3 & Birds & & 4.150 & 0.005 & 0.400 & 83.051 & $\overline{0.864}$ & $\overline{0.005}$ \\
\hline 4 & Sharks & & 4.052 & 0.682 & 0.600 & 3.000 & $\overline{0.653}$ & $\underline{0.200}$ \\
\hline 5 & Rays and skates & & 3.799 & 1.400 & 0.480 & 2.243 & 0.084 & $\underline{0.214}$ \\
\hline 6 & Cod & & 3.417 & 0.560 & 1.644 & 6.112 & $\overline{0.814}$ & $\overline{0.269}$ \\
\hline 7 & Haddock & & 3.148 & $\underline{0.384}$ & 1.370 & 7.542 & $\overline{0.950}$ & $\underline{0.182}$ \\
\hline 8 & Saithe & & 3.972 & $\overline{0.505}$ & 0.870 & 4.023 & $\underline{0.631}$ & $\underline{0.216}$ \\
\hline 9 & Whiting & & 3.402 & 0.785 & 1.450 & 5.460 & $\underline{\underline{0.995}}$ & $\underline{0.266}$ \\
\hline \multirow[t]{5}{*}{10} & Other demersals & & 3.419 & 2.622 & 0.816 & 2.726 & $\overline{0.950}$ & $\overline{0.299}$ \\
\hline & & Other demersals & 3.894 & $\underline{3.503}$ & 0.770 & 2.567 & 0.950 & $\overline{0.300}$ \\
\hline & & Gurnards & 3.691 & $\overline{0.150}$ & 1.400 & $\overline{4.610}$ & 0.638 & $\underline{0.304}$ \\
\hline & & Inshore fish & 3.585 & 0.207 & 5.000 & $\underline{16.667}$ & 0.711 & $\overline{0.300}$ \\
\hline & & Norway pout & 3.231 & 0.541 & 2.000 & 7.000 & 0.950 & 0.286 \\
\hline \multirow[t]{4}{*}{11} & Flatfish & & 3.277 & $\underline{1.785}$ & $\underline{0.929}$ & 3.097 & 0.950 & 0.300 \\
\hline & & Halibut, turbot, brill & 4.138 & 0.269 & $\overline{0.550}$ & 1.800 & $\underline{0.441}$ & $\underline{0.306}$ \\
\hline & & Plaice & 3.454 & 1.637 & 0.975 & 3.420 & $\overline{0.689}$ & $\overline{0.285}$ \\
\hline & & Sole & 3.377 & 0.456 & 0.800 & 2.700 & $\underline{0.910}$ & 0.296 \\
\hline 12 & Mackerel & & 3.334 & 0.835 & 0.626 & 3.950 & $\underline{0.972}$ & $\underline{0.158}$ \\
\hline 13 & Herring & & 3.187 & 1.827 & 1.800 & 10.100 & $\overline{0.950}$ & $\overline{0.178}$ \\
\hline 14 & Sandeels & & 3.328 & $\overline{0.849}$ & $\underline{1.826}$ & 6.085 & 0.950 & $\overline{0.300}$ \\
\hline \multirow[t]{4}{*}{15} & Other pelagic & & 3.310 & $\overline{9.806}$ & $\overline{1.216}$ & 4.958 & $\underline{0.377}$ & $\underline{0.245}$ \\
\hline & & Other pelagics & 3.795 & 4.326 & $\underline{0.869}$ & 2.895 & 0.221 & $\overline{0.300}$ \\
\hline & & Horse mackerel & 3.237 & 1.873 & $\overline{0.700}$ & 2.900 & $\underline{0.703}$ & 0.241 \\
\hline & & Sprat & 3.152 & $\underline{1.484}$ & 1.900 & 8.500 & $\overline{0.950}$ & 0.224 \\
\hline 16 & Crabs and lobsters & & 3.112 & $\underline{1.077}$ & 0.425 & $\underline{2.833}$ & 0.950 & 0.150 \\
\hline 17 & Nephrops & & 3.106 & 4.493 & 0.730 & 4.867 & $\underline{0.976}$ & 0.150 \\
\hline 18 & Prawns and shrimp & & 2.645 & 16.321 & 3.000 & $\overline{12.000}$ & $\overline{0.451}$ & 0.250 \\
\hline 19 & Cephalopods & & 3.198 & $\underline{0.446}$ & 1.981 & $\overline{15.000}$ & $\overline{0.950}$ & $\underline{0.132}$ \\
\hline \multirow[t]{6}{*}{20} & Other invertebrates & & 2.133 & $\overline{33.397}$ & 10.556 & 41.224 & $\underline{0.689}$ & $\underline{0.256}$ \\
\hline & & Other invertebrates & 2.666 & 7.305 & 6.000 & 24.000 & 0.950 & $\overline{0.250}$ \\
\hline & & Echinoderms & 3.001 & $\overline{3.945}$ & 4.000 & $\underline{16.000}$ & 0.924 & 0.250 \\
\hline & & Polychaetes & 2.037 & 10.000 & 5.000 & $\underline{16.667}$ & $\underline{0.430}$ & 0.300 \\
\hline & & Epifauna & 2.000 & 10.584 & 20.000 & $\overline{80.000}$ & $\overline{0.384}$ & 0.250 \\
\hline & & Infauna & 2.000 & 1.561 & 20.000 & 80.000 & $\underline{0.734}$ & 0.250 \\
\hline 21 & Large zooplankton & & 2.112 & 9.686 & 9.731 & 35.269 & $\overline{0.950}$ & $\underline{0.276}$ \\
\hline 22 & Small zooplankton & & 2.031 & $\overline{5.389}$ & 18.000 & 72.000 & 0.950 & $\overline{0.250}$ \\
\hline 23 & Phytoplankton & & 1.000 & $\overline{80.000}$ & 70.000 & 0.000 & $\underline{0.159}$ & \\
\hline 24 & Detritus & & 1.000 & 100.000 & & & $\overline{0.000}$ & \\
\hline
\end{tabular}

take zones, where these fleets cannot operate, to protect benthic communities. Cables in the Clyde Marine Region are buried or protected by rocks, eliminating the need to impose bottom trawl restrictions near cables.

\section{Ecopath with Ecosim model}

The EwE MSP model for the MSP Challenge Clyde Marine Region edition was built using the original Firth of Clyde EwE model (Heywood 2009) and the West Coast of Scotland model, originally developed by Haggan and Pitcher (2005) and recently updated by Alexander et al. (2015) and Serpetti et al. (2017).

The original Firth of Clyde model included 37 functional groups and was reduced to 24 groups for the purpose of MSP gameplay (Table 6). Similar to the North Sea case study, species of interest for MSP gameplay, such as commercial species, were retained as single-species functional groups, whereas others were merged into larger groups. Fishing fleets were aggregated into the fleets of importance to Clyde stakeholders and according to the pressures of interest to MSP gameplay (Table 7). The model was sensechecked and calibrated using PREBAL diagnostics (Link 2010) and best practice methods (Heymans et al. 2016).

The temporal dynamics of the model were validated using driving (fishing mortality) and calibration (biomass, catch) time series. Automated stepwise fitting mechanisms (Scott et al. 2016) were used to estimate the combination of vulnerabilities between functional groups that produced a best fitting model capable of capturing the trends of historic data (using sum of squares and AICc). A total of six predator vulnerabilities were estimated, suggesting top-down control from sharks, haddock, and Nephrops (Nephrops norvegicus), and bottom-up control from cod, saithe, and whiting (Merlangius merlangus). Estimated vulnerabilities reduced the models sum of squared deviations from 68 to 49 and AICc from -221 to -277 . 
Table 7. Fishing fleet structure, landings, and discards for the marine spatial planning challenge Clyde Sea Ecopath with Ecosim model. Fleets that include more than one of the fleets from the uncondensed Clyde Sea model are in bold font and their components are in italics.

\begin{tabular}{lllcc}
\hline \hline $\begin{array}{l}\text { Fleet } \\
\text { num- } \\
\text { ber }\end{array}$ & Fishing fleet type & Condensed fleets & $\begin{array}{c}\text { Landings } \\
\left(\text { tonne } / \mathrm{km}^{2}\right)\end{array}$ & $\begin{array}{c}\text { Discards } \\
\left.\text { (tonne } / \mathrm{km}^{2}\right)\end{array}$ \\
\hline 1 & Demersal trawl & & 0.73 & 0.39 \\
$\mathbf{2}$ & Scallop fleet & Dredge & $\mathbf{0 . 1 2}$ & $\mathbf{0 . 0 0}$ \\
& & Hand collecting & 0.03 & 0.00 \\
3 & Nephrops fleet & & 0.09 & 0.00 \\
4 & Pots and creels & & 0.01 & 1.70 \\
$\mathbf{5}$ & Seine & Seine & $\mathbf{0 . 8 3}$ & 0.0004 \\
& & Pelagic fleet & 0.41 & 0.00 \\
& & & 0.42 & 0.12 \\
\hline
\end{tabular}

The Ecospace map was defined at 93 rows by 67 columns at $1.5 \times$ $1.5 \mathrm{~km}$ cells to capture fine-scale planning activities in the area. The spatial distributions of species in the Firth of Clyde were determined by habitat preferences and functional responses to depth, whereas fleet activity was restricted by habitat type. Habitat types were grouped into five categories: mud, rock, sand, coarse sediment, and mixed sediment. The minimum, maximum, and optimum depths for functional groups were taken from AquaMaps (Kaschner et al. 2016), a global distribution model for marine species. AquaMaps depth tolerance ranges were converted into Gaussian functional responses and assigned to functional groups to determine their spatial distributions through the Ecospace HFCM. By using Gaussian response functions, the habitat capacity of functional groups were multiplied by 1 in Ecospace cells, which corresponded with their optimum depths having no diminishing effect. The multiplier, and therefore habitat capacity, declined in cells with depths greater or less than optimum, eventually reaching zero at tolerance extremes.

Similarly to the North Sea case study, functional responses to impacts were set based on low-high linear functional responses for functional groups most sensitive to MSP pressures. Seals and seabirds were given low negative functional responses to noise, whereas cetaceans were given a high negative response. Both seals and cetaceans were assigned low negative responses to bottom surface disturbance, whereas crabs and lobsters and other benthic invertebrates were assigned high negative responses to bottom disturbance (Table 8).

\section{Testing}

The Firth of Clyde EwE model was tested using various scenarios of hypothetical gameplay actions, following the aforementioned protocol, prior to integration in the MSP Challenge simulation platform. The individual and cumulative ecological impacts of noise, surface disturbance, bottom disturbance, and artificial substrate were tested on the Clyde Sea Ecospace model by subsetting a rectangular region toward the south of the Clyde model as a pressure-testing area. The effects of the pressures on the biomass of functional groups within and outside the pressure region were tested at increasing pressure intensities. The behaviour of the ecological model was publicly tested during game sessions with project participants, public audiences, and stakeholders as part of the wider SIMCelt project (Fairgrieve 2017)

The report detailing the simplification, temporal fitting, spatial setup, and pressure testing for the MSP Clyde Sea EwE model is available in Bentley et al. (2017).

\section{RESULTS}

\section{North Sea case study}

The introduction of MSP start-up pressures had the largest effects on cod, demersal predators, sandeel and sprat, small demersal fish, and large crabs. Individual pressures had different effects across the modeled components. Low-frequency noise only had a direct negative effect on a small number of functional groups such as cod, commercial gadoids, and demersal predators, whose displacement had positive effects on some prey and competing groups (e.g., herring, sandeel and sprat, small pelagic fish, flatfish, small demersal fish, large demersal fish, and large crabs). For some groups negatively affected by noise (e.g., herring), the net effect of noise was positive due to predator displacement. This result was observed across multiple groups and demonstrated that a food web model captures both direct and indirect effects of game pressures. Bottom disturbance had a negative effect on most groups except for pelagic fish such as mackerel, herring, and sandeel and sprat, and small demersal fish, which indirectly benefitted from disturbance-induced displacement of their predators. Surface disturbance had a negative effect on some groups, including windfarm-indifferent seabirds, cod, commercial gadoids, demersal predators, and mackerel. Other groups showed positive responses to surface disturbance (seals, windfarmavoiding seabirds, herring, sandeel and sprat) through food web dynamics.

Establishment of artificial habitat had a negative effect on most groups except for commercial gadoids, demersal predators, flatfish, large benthic invertebrates, and small benthic invertebrates, which either find extra habitat and shelter or increased prey availability through reduction of competing predators. Large crabs, which typically find highly favorable conditions in artificial habitat, showed a negative biomass trend under this effect. This result is because the favorable habitat conditions caused this functional group to aggregate, resulting in local depletion of food resources and higher vulnerability to predation. This result is a typical example of a nonlinear food web effect.

Protection had a positive effect on most species, in particular on intensely harvested fish species (e.g., herring, sandeel and sprat, mackerel, and flatfish) whose increasing biomasses supported larger biomass of their predators such as seals and both groups of seabirds. However, the effect of protection was negative for cod and demersal predators because fishing fleets banned from protected areas concentrated in the remaining open areas, increasing the overall impacts on these target groups.

For many groups, the overall effect of combined pressure profoundly differed from the effect of individual pressures (e.g., for cod, demersal predators, and sandeel and sprat) or even triggered inverse effects (e.g., for herring and mackerel, the combined pressure impacts were strongly negative, whereas all 
Table 8. Spatial pressures and drivers applied to functional groups and fishing fleets in the marine spatial planning challenge Clyde Sea Ecospace model. MPA = marine protected area.

\begin{tabular}{|c|c|c|c|}
\hline $\begin{array}{l}\text { Functional group or fishing } \\
\text { fleet }\end{array}$ & $\begin{array}{l}\text { Spatial driver or } \\
\text { pressure layer }\end{array}$ & Functional response & Dynamic pressure layer \\
\hline \multirow[t]{3}{*}{ Seals } & Depth & Gaussian & $\mathrm{N}$ \\
\hline & Noise & Linear (low negative impact) & $\mathrm{Y}$ \\
\hline & Surface disturbance & Linear (low negative impact) & $\mathrm{Y}$ \\
\hline \multirow{3}{*}{ Cetaceans } & Depth & Gaussian & $\mathrm{N}$ \\
\hline & Noise & Linear (high negative impact) & $\mathrm{Y}$ \\
\hline & Surface disturbance & Linear (low negative impact) & $\mathrm{Y}$ \\
\hline Birds & Noise & Linear (low negative impact) & $\mathrm{Y}$ \\
\hline Sharks & Depth & Gaussian & $\mathrm{N}$ \\
\hline Rays and skates & Depth & Gaussian & $\mathrm{N}$ \\
\hline Cod & Depth & Gaussian & $\mathrm{N}$ \\
\hline Haddock & Depth & Gaussian & $\mathrm{N}$ \\
\hline Saithe & Depth & Gaussian & $\mathrm{N}$ \\
\hline Whiting & Depth & Gaussian & $\mathrm{N}$ \\
\hline Flatfish & Depth & Gaussian & $\mathrm{N}$ \\
\hline Mackerel & Depth & Gaussian & $\mathrm{N}$ \\
\hline Herring & Depth & Gaussian & $\mathrm{N}$ \\
\hline Sandeels & Depth & Gaussian & $\mathrm{N}$ \\
\hline \multirow{2}{*}{ Crabs and lobsters } & Depth & Gaussian & $\mathrm{N}$ \\
\hline & Bottom disturbance & Linear (high negative impact) & $\mathrm{Y}$ \\
\hline Other invertebrates & Bottom disturbance & Linear (high negative impact) & $\mathrm{Y}$ \\
\hline Demersal trawl & MPA (demersal fleet) & Restricted entry & $\mathrm{Y}$ \\
\hline Scallop fleet & MPA (scallop fleet) & Restricted entry & $\mathrm{Y}$ \\
\hline Nephrops fleet & MPA (Nephrops fleet) & Restricted entry & $\mathrm{Y}$ \\
\hline Pots and creels & MPA (pots and creels) & Restricted entry & $\mathrm{Y}$ \\
\hline Seine & MPA (seine) & Restricted entry & $\mathrm{Y}$ \\
\hline
\end{tabular}

but one individual pressure had positive biomass effects). These results highlighted the nonlinear effects that take place throughout the food web and the interactions occurring between impacts.

Similarly, the spatial distributions of some groups were more affected than others (Figs. 5 and 6): cetaceans, seals, and seabirds showed higher or lower negative effects from shipping routes, windfarms, oil platforms, and submerged cables because of increased noise and surface disturbance. These groups displayed localized impacts, either positive or negative, from human activities. Predatory fish showed more even patterns due to the combination of fishing displacement and pressure effects on their spatial distribution vs. that of prey fish because top predator species with little or no fishing mortality were able to move away from impacts without repercussions, dispersing across their habitat. Most fish groups showed similar patterns to impacts from noise and surface and bottom disturbance interacting with the food web effects and fishing. Species generally avoided areas affected by human activities (shipping routes, oil and gas platforms, windfarms). Commercially important fish such as cod, commercial gadoids, demersal predators, and flatfish showed generally larger increases in the southern area of the North Sea. This was explained through reduced fishing pressure caused by much higher initial activity in the south than in the north. Benthic invertebrates and large crabs benefitted from artificial habitat for shelter and were most sensitive to bottom disturbance.

\section{Firth of Clyde case study}

The establishment of protection from fishing generated the largest biomass fluctuations of functional groups within the Firth of Clyde ecosystem. In response to MPA placement, the biomass of
Nephrops, crabs and lobsters, and rays and skates increased, whereas noticeable biomass decreases were observed for groups such as herring, sharks, and sandeels. The gradual addition of other pressures had only minor effects on the total biomass of functional groups in the Firth of Clyde. The cumulative impact of all start-up pressures on the total biomass of functional groups resembled the changes witnessed when MPAs were added independently, albeit with slight deviations.

The responses of functional groups to low-frequency noise and surface disturbance were much more apparent when viewed in a spatial context. Whereas the total biomass of functional groups showed little change under the implementation of these layers independently, the spatial distributions of many species, specifically seals, cetaceans, and seabirds, noticeably deviated to avoid noise and surface disturbance generated by shipping activities (Fig. 7). The impact of shipping intensity generated cascading food web effects in the Clyde food web model. The biomass distribution of mammals and seabirds decreased in areas of high noise and surface disturbance, leading to an increase in the biomass of pelagic and demersal fish due to reduced predation pressure, which then led to a decrease in the biomass of invertebrates due to increased predation pressure. The biomass of mammals and seabirds was redistributed to areas outside of shipping lanes, leading to biomass declines for their prey in these areas.

Invertebrate groups such as crabs and lobsters and Nephrops benefitted from the reduced fishing mortality within the MPAs, as illustrated by the increase in their biomass (Figs. 8 and 9). These MPAs did not directly protect demersal or pelagic fish, but instead displaced effort from demersal trawl and Nephrops fleets to the 
Fig. 5. North Sea biomass distribution and intensity changes up to $10 \%$ in response to the introduction of marine spatial planning start-up pressures after a 40-yr simulation period for various biological compartments. (A) Cetaceans. (B) Seals. (C) Windfarm-avoiding seabirds. (D) Windfarm-indifferent seabirds. (E) Cod. (F) Commercial gadoids. (G) Demersal predators. (H) Herring. (I) Sandeel and sprat. (J) Mackerel. (K) Flatfish. (L) Large demersal fish. (M) Large crabs. (N) Large benthic invertebrates. (O) Small benthic invertebrates.
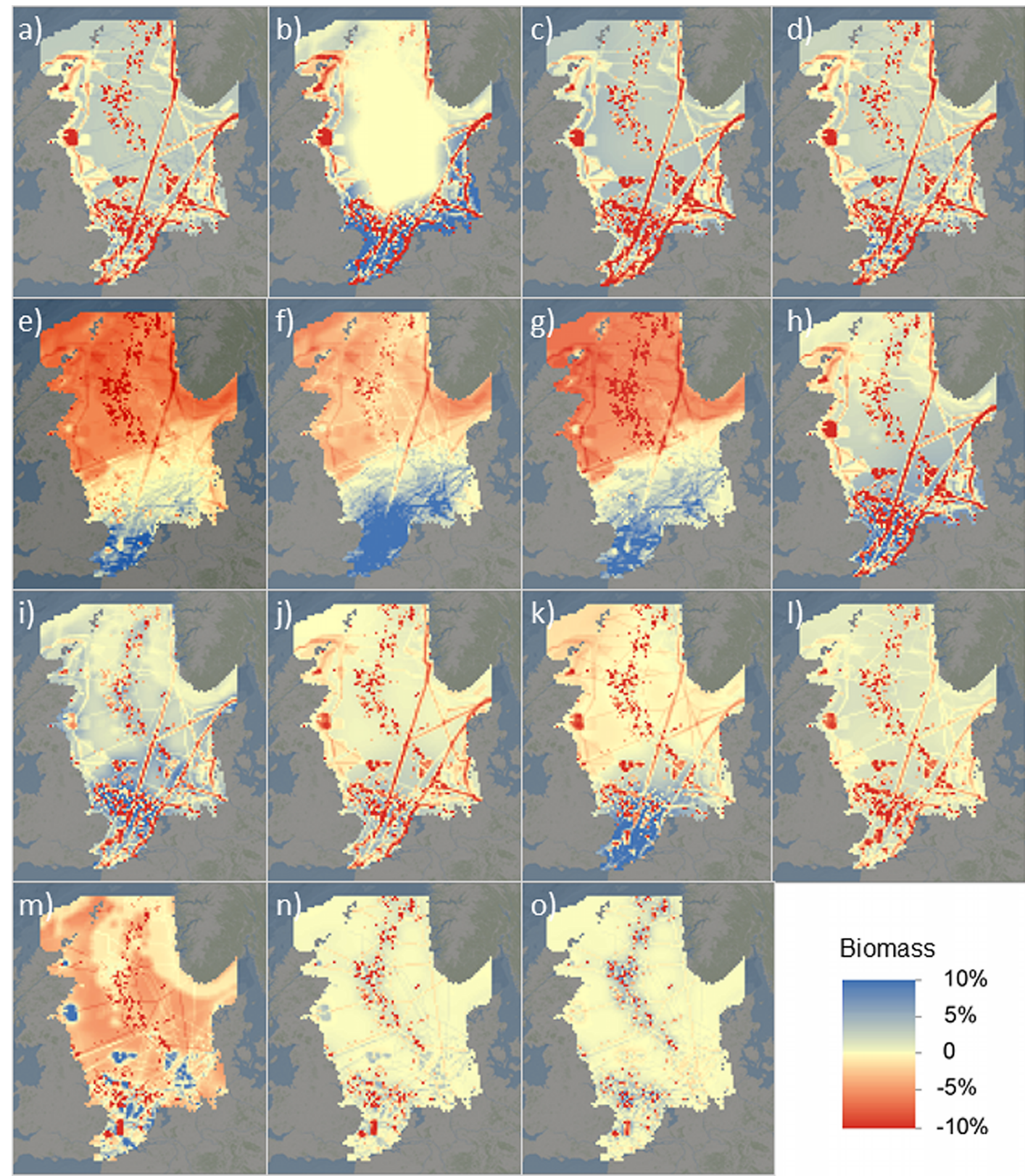

\section{Biomass}

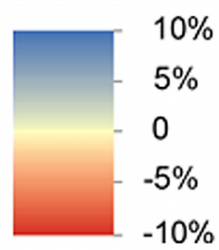

outer edge of the MPAs, where demersal and pelagic fish were found in greater abundance because of their preferences for increased depths. Therefore, despite the establishment of the protected areas, overall landings of demersal and pelagic species still increased because both species are caught by the seine fleet, which was granted access into the large MPAs.

Initial pressures of bottom disturbance and artificial habitat had negligible effects on the total biomass and overall biomass distribution of functional groups in the Firth of Clyde. This was not because of their lack of impact, but rather because of the low intensity and distribution of these pressures in the Clyde Marine Region. Despite this limited impact, the biomass of invertebrate groups increased in areas where artificial habitat had been created by the presence of ports and marinas. Invertebrate biomass declined in the presence of bottom disturbance. Whereas the extent of these pressure layers had minimal effects at the start of gameplay, spatial plans developed during game sessions showed 
Fig. 6. North Sea biomass distribution and intensity changes up to 5\% in response to the introduction of marine spatial planning start-up pressures after a 40-yr simulation period for various compartments. (A) Pelagic small gadoids. (B) Small pelagic fish. (C) Small demersal fish. (D) Squid and cuttlefish.
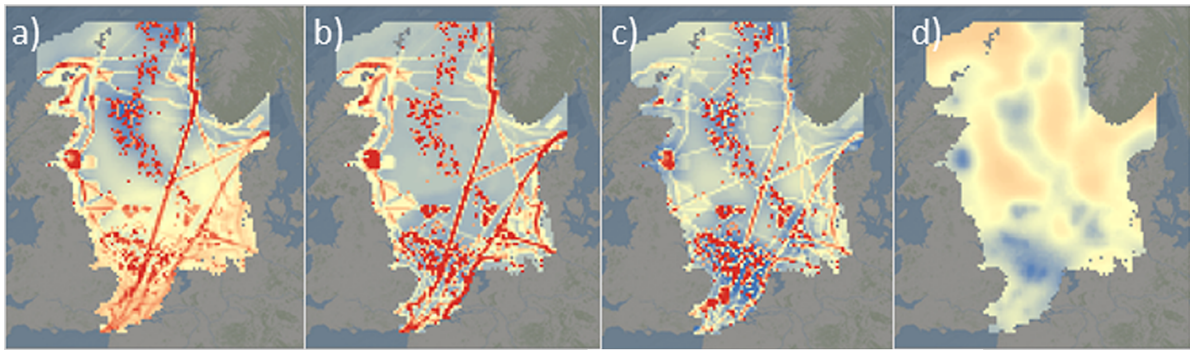

Biomass

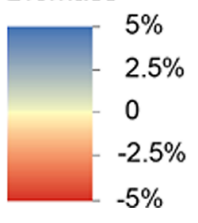

Fig. 7. Proportional change in the biomass of functional groups in the Firth of Clyde marine spatial planning (MSP)-Ecopath with Ecosim model after the implementation of gaming startup pressure layers. The baseline (0) denotes the biomass prior to the addition of environmental pressures. Hollow bars and points denote changes that are not explicitly shown to MSP game participants. MPAs $=$ marine protected areas .

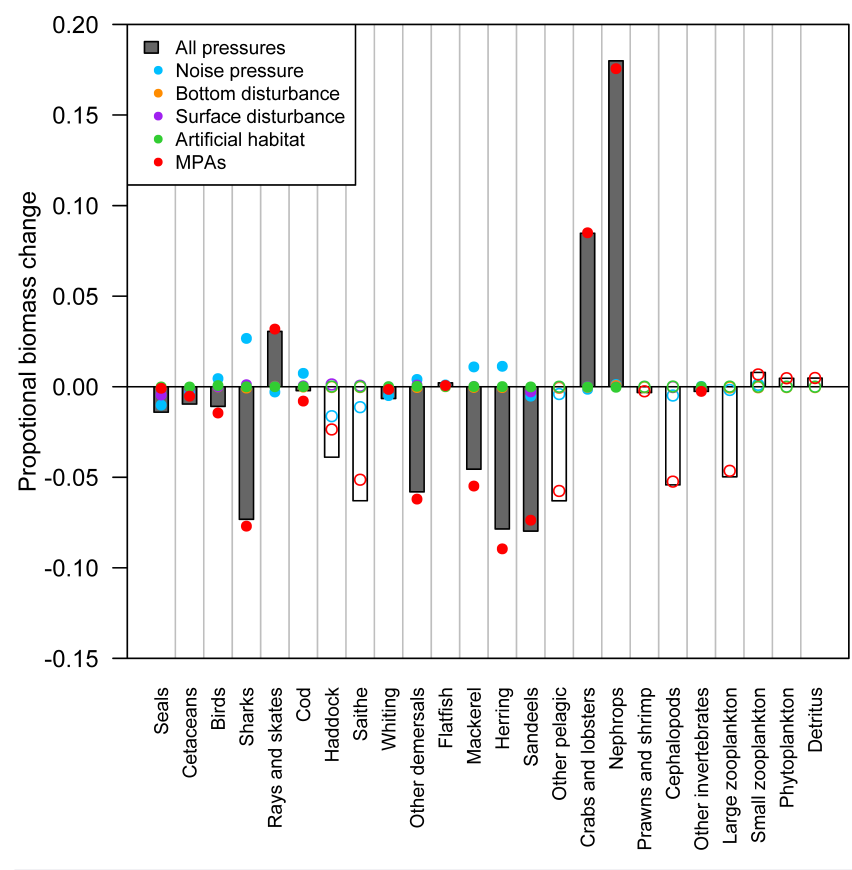

that player allocation of waste disposal sites or artificial structures could drastically influence the ecology of the Clyde Marine Region.

\section{DISCUSSION}

The MSP Challenge simulation platform, enhanced with the scientific ecosystem models presented here, has the potential to serve as a powerful planning support tool and learning environment, revealing ecological complexities and dynamics of marine food webs under the direct and indirect repercussions of planned human activities. Ecological conservation and marine renewable resource management are complex processes, especially
Fig. 8. Firth of Clyde biomass distribution and intensity changes up to $5 \%$ in response to the introduction of marine spatial planning start-up pressures after a $40-\mathrm{yr}$ simulation period for various compartments. (A) Seals. (B) Cetaceans. (C) Birds. (D) Sharks. (E) Rays and skates. (F) Cod. (G) Saithe. (H) Whiting. (I) Mackerel.

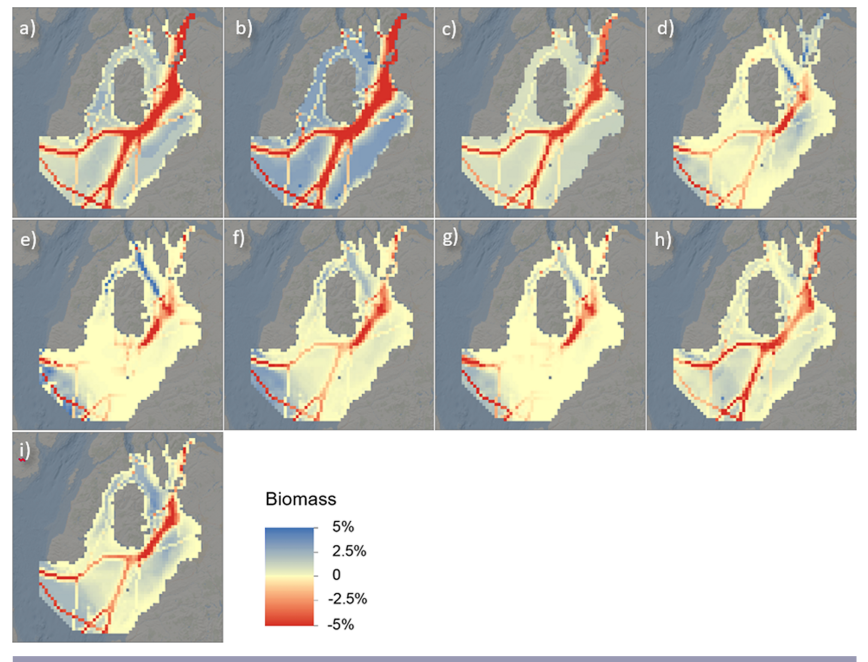

when tightly interwoven with the wide range of planning challenges offered by the MSP Challenge simulation platform. The cascading food web dynamics add ecological repercussions to the gameplay, which encourages players to pay attention to the ecosystem, rather than treating ecological issues as an afterthought.

\section{Lessons learned from the case studies}

We included two contrasting case studies to demonstrate the feasibility of adapting preexisting EwE models for inclusion in the MSP Challenge simulation platform with different characteristics and objectives. The introduction of anthropogenic disturbances at the start of the model runs altered the spatial distributions of functional groups (Fig. 10), deviating from the master models. This result was expected and unavoidable because these disturbances were not explicitly represented in the original models.

Models for the North Sea and Firth of Clyde showed different responses to the introduction of similar environmental effects. 
Fig. 9. Firth of Clyde biomass distribution and intensity changes up to $1 \%$ in response to the introduction of marine spatial planning start-up pressures after a 40-yr simulation period for various compartments. (A) Other pelagic. (B) Nephrops. (C) Prawns and shrimp. (D) Other invertebrates.
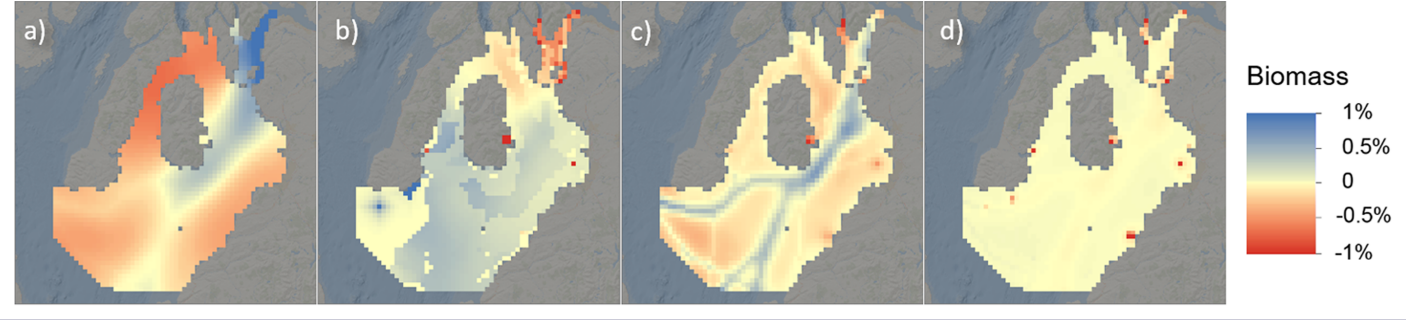

Fig. 10. Comparison of proportional changes in the biomass of ecological groups in the North Sea and Firth of Clyde marine spatial planning (MSP)-Ecopath with Ecosim models after the implementation of MSP start-up pressure layers. The baseline (0) denotes the biomass prior to the addition of these pressures. MPAs $=$ marine protected areas

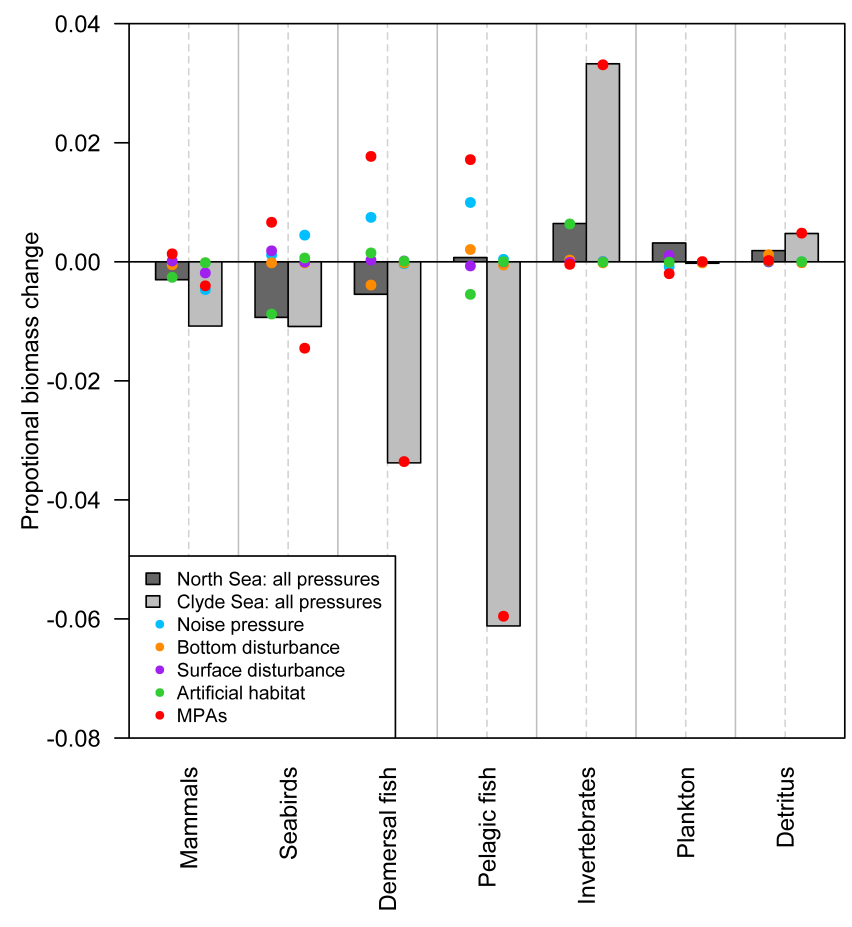

Several factors contribute to these differences: The North Sea and Firth of Clyde ecosystems greatly differ in ecological and physical characteristics, uses, impacts, and management mechanisms (Haggan and Pitcher 2005, Mackinson and Daskalov 2007, Alexander et al. 2015, Serpetti et al. 2017). Ecological responses to anthropogenic disturbances differed between the two regions because both areas experienced unique patterns of shipping intensity, waste disposal, renewable energy, etc. For example, no renewable energy structures exist in the Clyde, whereas windfarms were established in the North Sea; artificial habitat and its impacts were thus more prevalent in the North Sea than in the Firth of Clyde. Additionally, unique characteristics of the food web, environmental sensitivities of different species, and fishing unavoidably caused both models to respond differently to MSP disturbances.

Interestingly, our study shows that overall disturbances had significantly greater impacts in the Firth of Clyde model than in the North Sea, which was a direct consequence of the difference in modeled area between the models. Whereas mobile species in the North Sea had ample room to relocate in response to unfavorable conditions, functional groups in the Firth of Clyde were more spatially restricted, with predators and prey closely tied together within a smaller area.

\section{Challenges and limitations}

A significant limitation to our exercise was the need to use a simplified pressure system. Pressure categories such as noise, surface disturbance, and bottom disturbance are broad generalizations of much finer disturbances that could have wide ranges of impacts on marine animals if properly included in accordance with recent studies (Williams et al. 2015, Hawkins and Popper 2017, Platteeuw et al. 2017, Spence et al. 2018). Similarly, there are many types of artificial substrate that offer different benefits across ecosystems (e.g., Wright et al. 2020), and variety in marine protection schemes is broadly studied (Katsanevakis et al. 2011, Horta e Costa et al. 2016, Stelzenmüller et al. 2018). Because of limitations in computational power, we opted to include only the most iconic stressors into the EwE-MSP modeling approach, using generic environmental responses to evoke intuitive first-order responses of the ecosystem to these stressors that then mechanistically cascade through the food web. As scientific evidence of pressure impacts grows, we will need to revisit the pressure-response system, bringing more variety to the choice of environmental pressures to affect Ecospace.

Similarly, the use of simple linear response functions rather than evidence-based elaborate response curves was a simplification born out of a lack of data for all species included in functional group aggregations. We cross-validated first-order responses to MSP disturbances with expert opinion. Although a lack of rigorous validation introduced a significant amount of speculation into the modeling framework, there were simply no alternatives available to validate the impact of hypothetical MSP gameplay onto complex food webs; studies of the synergistic and antagonistic effects of multiple pressures are still rare because of inherent complexity (Coll et al. 2019). As such, the pressureresponse system on which this initial version of the MSP-EwE linkage was based will need refining when more empirical evidence and validation data become available. 


\section{Effectiveness}

With this study, we illustrated the enrichment of the MSP Challenge simulation platform with ecological dynamics. Participant responses to this first integration of a scientific model into the platform was strongly positive overall (Fairgrieve 2017, Jean et al. 2018, Abspoel et al. 2020). Through nonlinear effects such as spatial trophic cascades, food webs can produce unexpected effects crucial for providing a deeper understanding of ecological dynamics in response to changes in the use of marine space.

MSP test sessions indicated that overfamiliarity with the geography of a real-life area could hamper MSP Challenge uptake. Keijser et al. (2018) observed that perceptions among the participants differed greatly on the ground of familiarity with MSP processes: participants less familiar with MSP benefitted the most from the sessions. The authors hypothesize that MSP Challenge sessions are most effective for participants with limited personal knowledge or involvement with the sea area or specific sectoral interests. These potential challenges can be addressed via a well thought-out plan of objectives, roles, and goals for a given session, tailored to a specific audience, and calling for a specific role of the so-called game master and session moderator (Abspoel et al. 2020).

\section{Future work}

Because both MSP and EwE are data driven, new geographic areas, with different characteristics and a different ecosystem, can be incorporated into the simulation platform solely through data without requiring software changes. This factor makes it possible to develop new regional editions within an acceptable time frame and budget. As an example, together with Dalian University of Technology (China) and funded by the National Natural Science Foundation of China, we are preparing the development of a Bo Hai Bay edition of the MSP Challenge.

Other improvements include the following.

- The simulation platform itself can be improved and extended: The fisheries management system can be refined, with customizable harvest control rules (Mackinson et al. 2017) and detailed control over the functioning of MPAs (e. g., Christensen et al. 2009).

- Oceanic currents and larval stages of key food web components can be included to allow the MSP Challenge models to focus on larval connectivity between protected areas (Walters et al. 2010).

- Projections of climate change can be implemented to affect how the ability of marine animals to use the marine space may shift over time (Christensen et al. 2014).

- A refined action-pressure model with evidence-based functional responses should be developed to simulate species responses to anthropogenic pressures more realistically and address specific conservation concerns.

- A host of new spatially explicit ecological indicators could be added as potential outcomes to support different ways to explore the impacts on ecology, such as those defined in the EU-Marine Strategy Framework Directive (2008/56/EC; Coll and Steenbeek 2017).
Diversifying the amount and detail of the environmental drivers may hamper the ability to discern cause and effect; keeping the MSP Challenge simulation platform as simple as possible to optimize participant learning should remain a top priority. Additionally, including environmental change beyond MSP participant control may give rise to a perception that the simulations are out of control. Both factors thus risk adversely affecting participant engagement and learning (Westera 2017), despite providing increased predictive capabilities. This result, in the end, may defy the aim of the MSP Challenge simulation platform: engaging stakeholders and planners to learn about the complexity of MSP. When simulation run times are no longer a limiting constraint to EwE model complexity, the MSP-EwE connection could be leveraged at its full potential as a tool for planning support, with food webs, environmental forcing, and functional responses at sufficient detail to answer MSP questions, comprehensively validated with data, and a quantification of the various sources of uncertainty. This work can furthermore inspire and direct others challenged with the integration of a complex model into an advanced interactive planning support system. It serves as a springboard for the use of advanced game technology and gameplay for learning about managing complex systems and natural resources. Let's play.

Responses to this article can be read online at: http://www.ecologyandsociety.org/issues/responses. $\mathrm{php} / 11580$

\section{Acknowledgments:}

The MSP Challenge North Sea edition and Clyde Marine Region edition were co-funded by the EU Interreg NorthSEE and EU SimCelt projects, respectively. The link between MSP Challenge and EwE and the Ecopath model for the North Sea were partially funded by the Netherlands Ministry of Infrastructure and Water Management and Rijkswaterstaat. The Ecopath model for the Clyde Marine Region was partially funded by the Scottish Government. Research by first author J. S. is part of pending PhD research. Research by coauthor $X . K$. is part of pending PhD research on the use of serious gaming in (transboundary) maritime spatial planning at Wageningen University, The Netherlands, with support from Rijkswaterstaat. Research by co-author I. M. is cofunded by The National Natural Science Foundation of China (71774024). The MSP Challenge and Ecopath modeling approach are open-source, community-based, not-for-profit initiatives. Breda University of Applied Sciences, the Netherlands, is custodian of the MSP Challenge Simulation Platform. All organizations and persons who contribute to the MSP Challenge are credited at the user community wiki accessible through the website http://www. mspchallenge.info. We express gratitude to Dr. Steve Mackinson and Dr. Chris Lynam at CEFAS for providing the North Sea model and for their support in adapting the model for maritime spatial planning purposes. We also wish to acknowledge EuroMarine for their funding of the scenario building workshop in Sète, France, in 2015, which led to the discussions and subsequent collaborations that produced the MSP-EwE merger. Without the support of EuroMarine, this paper would not have been written. 


\section{Data Availability Statement:}

The datalcode and auxiliary documentation that support this study are publicly available in figshare at https:/Ifigshare.com/accountl home\#/projects/28887

\section{LITERATURE CITED}

Abspoel, L., I. Mayer, X. Keijser, H. Warmelink, R. Fairgrieve, M. Ripken, A. Abramic, A. Kannen, R. Cormier, and S. Kidd. 2020. Communicating maritime spatial planning: the MSP Challenge approach. Marine Policy, in press. https://doi. org/10.1016/j.marpol.2019.02.057

Alexander, K. A., J. J. Heymans, S. Magill, M. T. Tomczak, S. J. Holmes, and T. A. Wilding. 2015. Investigating the recent decline in gadoid stocks in the west of Scotland shelf ecosystem using a foodweb model. ICES Journal of Marine Science 72(2):436-449. https://doi.org/10.1093/icesjms/fsu149

Baine, M. 2001. Artificial reefs: a review of their design, application, management and performance. Ocean and Coastal Management 44(3-4):241-259. https://doi.org/10.1016/S0964-5691 (01)00048-5

Bentley, J., J. Steenbeek, N. Serpetti, and J. J. Heymans. 2017. Refinement of an Ecopath with Ecosim (EwE) model of the Clyde Sea for use within the Clyde Marine Region digital Maritime Spatial Planning (MSP) Challenge Game. Unpublished paper. Figshare, Iasi, Romania. [online] URL: https://doi.org/10.6084/ $\underline{\text { m9.figshare. } 12458279}$

Burnham, K. P., and D. R. Anderson. 2002. Model selection and multimodel inference: a practical information-theoretic approach. Springer, New York, New York, USA.

Buxton, R. T., R. Galvan, M. F. McKenna, C. L. White, and V. Seher. 2017. Visitor noise at a nesting colony alters the behavior of a coastal seabird. Marine Ecology Progress Series 570:233-246. https://doi.org/10.3354/meps12073

Christensen, V., M. Coll, J. Steenbeek, J. Buszowski, D. Chagaris, and C. J. Walters. 2014. Representing variable habitat quality in a spatial food web model. Ecosystems 17(8):1397-1412. https:// doi.org/10.1007/s10021-014-9803-3

Christensen, V., Z. Ferdaña, and J. Steenbeek. 2009. Spatial optimization of protected area placement incorporating ecological, social and economical criteria. Ecological Modelling 220(19):2583-2593. https://doi.org/10.1016/j.ecolmodel.2009.06.029

Christensen, V., and C. J. Walters. 2004. Ecopath with Ecosim: methods, capabilities and limitations. Ecological Modelling 172 (2-4):109-139. https://doi.org/10.1016/j.ecolmodel.2003.09.003

Coll, M., M. G. Pennino, J. Steenbeek, J. Sole, and J. M. Bellido. 2019. Predicting marine species distributions: complementarity of food-web and Bayesian hierarchical modelling approaches. Ecological Modelling 405:86-101. https://doi.org/10.1016/j. ecolmodel.2019.05.005

Coll, M., and J. Steenbeek. 2017. Standardized ecological indicators to assess aquatic food webs: the ECOIND software plug-in for Ecopath with Ecosim models. Environmental Modelling and Software 89:120-130. https://doi.org/10.1016/j. envsoft.2016.12.004 de Mutsert, K., K. Lewis, S. Milroy, J. Buszowski, and J. Steenbeek. 2017. Using ecosystem modeling to evaluate tradeoffs in coastal management: effects of large-scale river diversions on fish and fisheries. Ecological Modelling 360(Supplement C):14-26. https://doi.org/10.1016/j.ecolmodel.2017.06.029

Douvere, F., and C. N. Ehler. 2009. New perspectives on sea use management: initial findings from European experience with marine spatial planning. Journal of Environmental Management 90(1):77-88. https://doi.org/10.1016/j.jenvman.2008.07.004

Duke, R. D. 1974. Gaming: the future's language. Sage, Beverly Hills, California, USA.

Engelhard, G. H., C. P. Lynam, B. García-Carreras, P. J. Dolder, and S. Mackinson. 2015. Effort reduction and the large fish indicator: spatial trends reveal positive impacts of recent European fleet reduction schemes. Environmental Conservation 42:227-236. https://doi.org/10.1017/S0376892915000077

European Commission. 2007. Opinion of the European Economic and Social Committee on the communication from the Commission to the European Parliament, the Council, the European Economic and Social Committee and the Committee of the Regions - an integrated maritime policy for the European Union COM(2007) 575 final. Official Journal of the European Union C211/31. Publications Office of the European Union, Luxembourg. [online] URL: https://eur-lex.europa.eu/legalcontent/EN/AUTO/?uri=uriserv:OJ.C .2008.211.01.0031.01.ENG\&toc= OJ:C:2008:211:FULL

European Commission. 2014. Directive 2014/89/EU of the European Parliament and of the Council of 23 July 2014 establishing a framework for maritime spatial planning. Official Journal of the European Union L257/135. Publications Office of the European Union, Luxembourg. [online] URL: http://data. europa.eu/eli/dir/2014/89/oj

Fairgrieve, R. 2017. Report on potential approaches for stakeholder engagement on MSP and pilot testing at local transboundary level - Clyde case study: using 'serious games' in cross-border marine planning: an innovative approach to stakeholder engagement piloted in the Clyde Marine Region, Scotland (D9). EASME/ EMFF/2014/1.2.1.5/3/SI2.719473 MSP Lot 3. University College Cork, Cork, Ireland. [online] URL: http://www.simcelt.eu/wpcontent/uploads/D9_Stakeholder-Engagement-at-Local-TransboundaryLevel.pdf

Foden, J., S. I. Rogers, and A. P. Jones. 2010. Recovery of UK seabed habitats from benthic fishing and aggregate extractiontowards a cumulative impact assessment. Marine Ecology Progress Series 411:259-270. https://doi.org/10.3354/meps08662

Foley, M. M., B. S. Halpern, F. Micheli, M. H. Armsby, M. R. Caldwell, C. M. Crain, E. Prahler, N. Rohr, D. Sivas, M. W. Beck, M. H. Carr, L. B. Crowder, J. E. Duffy, S. D. Hacker, K. L. McLeod, S. R. Palumbi, C. H. Peterson, H. M. Regan, M. H. Ruckelshaus, P. A. Sandifer, and R. S. Steneck. 2010. Guiding ecological principles for marine spatial planning. Marine Policy 34(5):955-966. https://doi.org/10.1016/j.marpol.2010.02.001

Forney, K. A., B. L. Southall, E. Slooten, S. Dawson, A. J. Read, R. W. Baird, and R. L. Brownell Jr. 2017. Nowhere to go: noise impact assessments for marine mammal populations with high site fidelity. Endangered Species Research 32:391-413. https://doi. org/10.3354/esr00820 
Gill, A. B. 2005. Offshore renewable energy: ecological implications of generating electricity in the coastal zone. Journal of Applied Ecology 42(4):605-615. https://doi.org/10.1111/ j.1365-2664.2005.01060.x

Gomez, C., J. W. Lawson, A. J. Wright, A. D. Buren, D. Tollit, and V. Lesage. 2016. A systematic review on the behavioural responses of wild marine mammals to noise: the disparity between science and policy. Canadian Journal of Zoology 94(12):801-819. https://doi.org/10.1139/cjz-2016-0098

Graham, I. M., E. Pirotta, N. D. Merchant, A. Farcas, T. R. Barton, B. Cheney, G. D. Hastie, and P. M. Thompson. 2017. Responses of bottlenose dolphins and harbor porpoises to impact and vibration piling noise during harbor construction. Ecosphere 8(5):e01793. https://doi.org/10.1002/ecs2.1793

Haggan, N., and T. Pitcher, editors. 2005. Ecosystem simulation models of Scotland's West Coast and sea lochs. Fisheries Centre Research Reports 13(4). [online] URL: http://hdl.handle. $\underline{\text { net } / 2429 / 47116}$

Hawkins, A. D., and A. N. Popper. 2017. A sound approach to assessing the impact of underwater noise on marine fishes and invertebrates. ICES Journal of Marine Science 74(3):635-651. https://doi.org/10.1093/icesjms/fsw205

Healey, P. 1996. The communicative turn in planning theory and its implications for spatial strategy formations. Environment and Planning B: Planning and Design 23(2):217-234. https://doi. org/10.1068/b230217

Heymans, J. J., M. Coll, J. S. Link, S. Mackinson, J. Steenbeek, C. Walters, and V. Christensen. 2016. Best practice in Ecopath with Ecosim food-web models for ecosystem-based management. Ecological Modelling 331:173-184. https://doi.org/10.1016/j. ecolmodel.2015.12.007

Heywood, E. 2009. Investigating the environmental impacts and sustainability of the Clyde Sea Norway lobster fishery through and ecosystem modelling approach. Dissertation. Imperial College London, London, UK.

Hinz, H., V. Prieto, and M. J. Kaiser. 2009. Trawl disturbance on benthic communities: chronic effects and experimental predictions. Ecological Applications 19(3):761-773. https://doi. org/10.1890/08-0351.1

Horta e Costa, B., J. Claudet, G. Franco, K. Erzini, A. Caro, and E. J. Gonçalves. 2016. A regulation-based classification system for marine protected areas (MPAs). Marine Policy 72:192-198. https://doi.org/10.1016/j.marpol.2016.06.021

International Council for the Exploration of the Sea (ICES). 2015. Report of the Working Group on Multispecies Assessment Methods (WGSAM). ICES CM 2015/SSGEPI:20. International Council for the Exploration of the Sea, Copenhagen, Denmark. [online] URL: http://www.diva-portal.se/smash/get/diva2:929847/ FULLTEXT01.pdf

Jean, S., L. Gilbert, W. Medema, X. Keijser, I. Mayer, A. Inam, and J. Adamowski. 2018. Serious games as planning support systems: learning from playing Maritime Spatial Planning Challenge 2050. Water 10(12):1786. https://doi.org/10.3390/ w10121786
Jones, E., B. McConnell, C. Sparling, and J. Matthiopoulos. 2013. Grey and harbour seal density maps. Marine Mammal Scientific Support Research Programme MMSS/001/11. Sea Mammal Research Unit report to the Scottish Government. University of St. Andrews, St. Andrews, UK. [online] URL: http://www.smru. st-andrews.ac.uk/files/2015/10/MR5_Seal_density_maps.pdf

Kannen, A. 2014. Challenges for marine spatial planning in the context of multiple sea uses, policy arenas and actors based on experiences from the German North Sea. Regional Environmental Change 14:2139-2150. https://doi.org/10.1007/s10113-012-0349-7

Karpouzi, V. S., R. Watson, and D. Pauly. 2007. Modelling and mapping resource overlap between seabirds and fisheries on a global scale: a preliminary assessment. Marine Ecology Progress Series 343:87-99. https://doi.org/10.3354/meps06860

Kaschner, K., K. Kesner-Reyes, C. Garilao, J. Rius-Barile, J. Rees, and R. Froese. 2016. AquaMaps: predicted range maps for aquatic species. Version 08/2016c. [online] URL: http://www.aquamaps. org/

Katsanevakis, S., V. Stelzenmüller, A. South, T. K. Sørensen, P. J. S. Jones, S. Kerr, F. Badalamenti, C. Anagnostou, P. Breen, G. Chust, G. D'Anna, M. Duijn, T. Filatova, F. Fiorentino, H. Hulsman, K. Johnson, A. P. Karageorgis, I. Kröncke, S. Mirto, C. Pipitone, S. Portelli, W. Qiu, H. Reiss, D. Sakellariou, M. Salomidi, L. van Hoof, V. Vassilopoulou, T. V. Fernández, S. Vöge, A. Weber, A. Zenetos, and R. ter Hofstede. 2011. Ecosystembased marine spatial management: review of concepts, policies, tools, and critical issues. Ocean and Coastal Management 54 (11):807-820. https://doi.org/10.1016/j.ocecoaman.2011.09.002

Keijser, X., M. Ripken, I. Mayer, H. Warmelink, L. Abspoel, R. Fairgrieve, and C. Paris. 2018. Stakeholder engagement in maritime spatial planning: the efficacy of a serious game approach. Water 10(6):724. https://doi.org/10.3390/w10060724

Ketten, D. R. 2012. Marine mammal auditory system noise impacts: evidence and incidence. Pages 207-212 in A. N. Popper and A. Hawkins, editors. The effects of noise on aquatic life. Springer, New York, New York, USA. https://doi. org/10.1007/978-1-4419-7311-5_46

Link, J. S. 2010. Adding rigor to ecological network models by evaluating a set of pre-balance diagnostics: a plea for PREBAL. Ecological Modelling 221(12):1580-1591. https://doi.org/10.1016/ j.ecolmodel.2010.03.012

Lusseau, D. 2003. Effects of tour boats on the behavior of bottlenose dolphins: using Markov chains to model anthropogenic impacts. Conservation Biology 17(6):1785-1793. https://doi.org/10.1111/j.1523-1739.2003.00054.X

Machernis, A. F., J. R. Powell, L. K. Engleby, and T. R. Spradlin. 2018. An updated literature review examining the impacts of tourism on marine mammals over the last fifteen years (2000-2015) to inform research and management programs. NOAA Technical Memorandum NMFS-SER-7. National Oceanic and Atmospheric Administration, National Marine Fisheries Service, Southeast Regional Office, St. Petersburg, Florida, USA. [online] URL: https://doi.org/10.7289/V5/TM-NMFS-SER-7

Mackinson, S., and G. Daskalov. 2007. An ecosystem model of the North Sea to support an ecosystem approach to fisheries management: description and parameterisation. Science Series 
Technical Report 142. Centre for Environment, Fisheries and Aquaculture Science, Lowestoft, UK. [online] URL: https://www. cefas.co.uk/publications/techrep/tech142.pdf

Martell, S. J. D., T. E. Essington, B. Lessard, J. F. Kitchell, C. J. Walters, and C. H. Boggs. 2005. Interactions of productivity, predation risk, and fishing effort in the efficacy of marine protected areas for the central Pacific. Canadian Journal of Fisheries and Aquatic Sciences 62(6):1320-1336. https://doi. org/10.1139/f05-114

Mayer, I. 2016. Playful organisations and learning systems. NHTV Breda University of Applied Science, Breda, The Netherlands. [online] URL: https://pure.buas.nl/ws/portalfiles/portal/683131/ Mayer_Playful_organisations_and_learning_systems.pdf

Mayer, I., Q. Zhou, J. Lo, L. Abspoel, X. Keijser, E. Olsen, E. Nixon, and A. Kannen. 2013. Integrated, ecosystem-based Marine Spatial Planning: design and results of a game-based, quasi-experiment. Ocean and Coastal Management 82 (Supplement C):7-26. https://doi.org/10.1016/j.ocecoaman.2013.04.006

Menegon, S., D. Depellegrin, G. Farella, E. Gissi, M. Ghezzo, A. Sarretta, C. Venier, and A. Barbanti. 2018. A modelling framework for MSP-oriented cumulative effects assessment. Ecological Indicators 91:171-181. https://doi.org/10.1016/j. ecolind.2018.03.060

Mikkelsen, L., M. Johnson, D. M. Wisniewska, A. van Neer, U. Siebert, P. T. Madsen, and J. Teilmann. 2019. Long-term sound and movement recording tags to study natural behavior and reaction to ship noise of seals. Ecology and Evolution 9 (5):2588-2601. https://doi.org/10.1002/ece3.4923

Muro, M., and P. Jeffrey. 2008. A critical review of the theory and application of social learning in participatory natural resource management processes. Journal of Environmental Planning and Management 51(3):325-344. https://doi.org/10.1080/09640560801977190

Pålsson, J., and J. S. Crona. 2017. Symphony - a tool for ecosystem-based marine spatial planning. Swedish Agency for Marine and Water Management, Göteborg, Sweden. [online] URL: https://www.havochvatten.se/en/swam/eu--international/ marine-spatial-planning/symphony---a-tool-for-ecosystem-basedmarine-spatial-planning.html

Peck, M. A., C. Arvanitidis, M. Butenschön, D. M. Canu, E. Chatzinikolaou, A. Cucco, P. Domenici, J. A. Fernandes, L. Gasche, K. B. Huebert, M. Hufnagl, M. C. Jones, A. Kempf, F. Keyl, M. Maar, S. Mahévas, P. Marchal, D. Nicolas, J. K. Pinnegar, E. Rivot, S. Rochette, A. F. Sell, M. Sinerchia, C. Solidoro, P. J. Somerfield, L. R. Teal, M. Travers-Trolet, and K. E. van de Wolfshaar. 2018. Projecting changes in the distribution and productivity of living marine resources: a critical review of the suite of modelling approaches used in the large European project VECTORS. Estuarine, Coastal and Shelf Science 201:40-55. https://doi.org/10.1016/j.ecss.2016.05.019

Perkol-Finkel, S., and Y. Benayahu. 2005. Recruitment of benthic organisms onto a planned artificial reef: shifts in community structure one decade post-deployment. Marine Environmental Research 59(2):79-99. https://doi.org/10.1016/j.marenvres.2004.03.122

Pınarbaşı, K., I. Galparsoro, Á. Borja, V. Stelzenmüller, C. N. Ehler, and A. Gimpel. 2017. Decision support tools in marine spatial planning: present applications, gaps and future perspectives. Marine Policy 83:83-91. https://doi.org/10.1016/j. marpol.2017.05.031

Platteeuw, M., J. Bakker, I. van den Bosch, A. Erkman, M. Graafland, S. Lubbe, and M. Warnas. 2017. A framework for assessing ecological and cumulative effects (FAECE) of offshore wind farms on birds, bats and marine mammals in the southern North Sea. Pages 219-237 in J. Köppel, editor. Wind energy and wildlife interactions. Springer, Cham, Switzerland. https://doi. org/10.1007/978-3-319-51272-3 13

Mackinson, S., M. Platts, J. Buzowski, J. Steenbeek, C. Walters, S. Hadeler, A. Rossberg, C. Garcia, and C. Lynam. 2017. Management strategy evaluation toolkit for Ecopath with Ecosim (model output and technical report). Centre for Environment, Fisheries and Aquaculture Science, Lowestoft, UK. https://doi. org/10.14466/CefasDataHub.44

Polovina, J. J. 1984. Model of a coral reef ecosystem. Coral Reefs 3(1):1-11. https://doi.org/10.1007/BF00306135

Redfern, J. V., M. F. McKenna, T. J. Moore, J. Calambokidis, M. L. Deangelis, E. A. Becker, J. Barlow, K. A. Forney, P. C. Fiedler, and S. J. Chivers. 2013. Assessing the risk of ships striking large whales in marine spatial planning. Conservation Biology 27 (2):292-302. https://doi.org/10.1111/cobi.12029

Romagnoni, G. 2019. Building, balancing, fitting and calibrating a simplified Ecopath with Ecosim North Sea model for the MSP Challenge Platform Edition game. Project 38-2-2-15. Interreg North Sea Region, Viborg, Denmark. [online] URL: $\underline{\text { https:// }}$ northsearegion.eu/media/10159/northsee-ewe-north-sea-modelreport august-2019.pdf

Romagnoni, G., S. Mackinson, J. Hong, and A. M. Eikeset. 2015. The Ecospace model applied to the North Sea: evaluating spatial predictions with fish biomass and fishing effort data. Ecological Modelling 300:50-60. https://doi.org/10.1016/j.ecolmodel.2014.12.016

Scott, E., N. Serpetti, J. Steenbeek, and J. J. Heymans. 2016. A stepwise fitting procedure for automated fitting of Ecopath with Ecosim models. SoftwareX 5:25-30. https://doi.org/10.1016/j. softx.2016.02.002

Serpetti, N., A. R. Baudron, M. T. Burrows, B. L. Payne, P. Helaouët, P. G. Fernandes, and J. J. Heymans. 2017. Impact of ocean warming on sustainable fisheries management informs the ecosystem approach to fisheries. Scientific Reports 7:13438. https://doi.org/10.1038/s41598-017-13220-7

Shannon, C. E. 1948. A mathematical theory of communication. Bell System Technical Journal 27(3):379-423. https://doi. org/10.1002/j.1538-7305.1948.tb01338.X

Spence, M. A., J. L. Blanchard, A. G. Rossberg, M. R. Heath, J. J. Heymans, S. Mackinson, N. Serpetti, D. C. Speirs, R. B. Thorpe, and P. G. Blackwell. 2018. A general framework for combining ecosystem models. Fish and Fisheries 19(6):1031-1042. https://doi. org/10.1111/faf. 12310

Steenbeek, J. 2018. MSP Challenge 2050 food web review. Dataset. Figshare, Iasi, Romania. [online] URL: https://doi.org/10.6084/ m9.figshare.5851821.v2 
Steenbeek, J., M. Coll, L. Gurney, F. Mélin, N. Hoepffner, J. Buszowski, and V. Christensen. 2013. Bridging the gap between ecosystem modeling tools and geographic information systems: driving a food-web model with spatial-temporal data. Ecological Modelling 263(10):139-151. https://doi.org/10.1016/j.

ecolmodel.2013.04.027

Stelzenmüller, V., M. Coll, A. D. Mazaris, S. Giakoumi, S. Katsanevakis, M. E. Portman, R. Degen, P. Mackelworth, A. Gimpel, P. G. Albano, V. Almpanidou, J. Claudet, F. Essl, T. Evagelopoulos, J. J. Heymans, T. Genov, S. Kark, F. Micheli, M. G. Pennino, G. Rilov, B. Rumes, J. Steenbeek, and H. Ojaveer. 2018. A risk-based approach to cumulative effect assessments for marine management. Science of the Total Environment 612:1132-1140. https://doi.org/10.1016/j.scitotenv.2017.08.289

Tamis, J. E., P. de Vries, R. H. Jongbloed, S. Lagerveld, R. G. Jak, C. C. Karman, J. T. Van der Wal, D. M. E. Slijkerman, and C. Klok. 2016. Toward a harmonized approach for environmental assessment of human activities in the marine environment. Integrated Environmental Assessment and Management 12 (4):632-642. https://doi.org/10.1002/ieam.1736

Walters, C. J., V. Christensen, W. Walters, and K. Rose. 2010. Representation of multistanza life histories in Ecospace models for spatial organization of ecosystem trophic interaction patterns. Bulletin of Marine Science 86(2):439-459. [online] URL: https:// www.ingentaconnect.com/contentone/umrsmas/ bullmar/2010/00000086/00000002/art00017

Walters, C., D. Pauly, and V. Christensen. 1999. Ecospace: prediction of mesoscale spatial patterns in trophic relationships of exploited ecosystems, with emphasis on the impacts of marine protected areas. Ecosystems 2(6):539-554. https://doi.org/10.1007/ $\underline{\mathrm{s} 100219900101}$

Westera, W. 2017. How people learn while playing serious games: a computational modelling approach. Journal of Computational Science 18:32-45. https://doi.org/10.1016/j.jocs.2016.12.002

Williams, R., A. J. Wright, E. Ashe, L. K. Blight, R. Bruintjes, R. Canessa, C. W. Clark, S. Cullis-Suzuki, D. T. Dakin, C. Erbe, P. S. Hammond, N. D. Merchant, P. D. O'Hara, J. Purser, A. N. Radford, S. D. Simpson, L. Thomas, and M. A. Wale. 2015. Impacts of anthropogenic noise on marine life: publication patterns, new discoveries, and future directions in research and management. Ocean and Coastal Management 115:17-24. https:// doi.org/10.1016/j.ocecoaman.2015.05.021

Wright, S. R., C. P. Lynam, D. A. Righton, J. Metcalfe, E. Hunter, A. Riley, L. Garcia, P. Posen, and K. Hyder. 2020. Structure in a sea of sand: fish abundance in relation to man-made structures in the North Sea. ICES Journal of Marine Science 77

(3):1206-1218. https://doi.org/10.1093/icesjms/fsy142 


\section{Appendix 1}

Here we summarize key characteristics of the Ecopath with Ecosim (EwE) food web modelling approach, and relevant mechanisms of EwE for the Maritime Spatial Planning Challenge platform dynamics.

\section{Ecopath}

The foundation of the Ecopath with Ecosim (EwE) modelling approach, Ecopath, is a massbalanced model that represents the energy flow in a food web (Polovina 1984, Christensen and Pauly 1992). Living components in the food web are represented as functional groups, which can be a single species, a combination of species with similar roles in the ecosystem, or discrete life stages of a single species.

Ecopath uses a system of linear equations to describe the average flows of mass and energy between functional groups over a period of time, typically a year, which can be summarized as follows:

$B_{i} \cdot\left(\frac{P}{B}\right)_{j}=\sum B_{j} \cdot\left(\frac{Q}{B}\right)_{j} \cdot D C_{j i}+B A_{i}+E_{i}+Y_{i}+B_{i} \cdot\left(\frac{P}{B}\right)_{i} \cdot\left(1-E E_{i}\right)$

where, for functional groups $i$ and $j, B$ is biomass; $P / B$ is production per unit of biomass; $B A$ is biomass accumulation rate; $E$ is net migration rate (emigration - immigration); $Y$ is total fishery catch rate; $E E$ is 'ecotrophic efficiency', defined as the proportion of the production that is utilized in the system; $Q / B$ is consumption per unit of biomass; and $D C_{j i}$ the fraction of prey $i$ in the diet of predator $j$.

For each group, Ecopath requires values for $B, Q / B, P / B, D C, Y$, and other values are optional. Of $B, P / B, Q / B$, and $E E$, three values must be entered while the fourth will be estimated by the model (Christensen and Pauly 1992 p. 1, Christensen and Walters 2004).

\section{Ecosim}

The temporal module of EwE, Ecosim, applies the mass-balanced Ecopath parameters, augmented with a few extra parameters related to behavior and temporal dynamics, to a series of time-dependent differential equations, expressing the biomass growth rate as:

$\frac{d B_{i}}{d t}=g_{i} \cdot \sum Q_{j i}-\sum Q_{i j}+I_{j i}-\left(M_{i}+F_{i}+e_{i}\right)_{i} \cdot B_{i}$

where, for functional groups $i$ and $j, d B / d t$ represents growth rate during time interval $d t ; g$ is net growth efficiency $(P / Q) ; I$ is immigration rate; $M$ is natural mortality rate; $F$ is fishing mortality rate; $e$ is emigration rate.

Ecosim stabilizes its food web dynamics through the concept of the foraging arena, which expresses that through predator avoidance behavior, at any given moment in time, only a fraction of a total prey biomass is vulnerable to predation by a predator (Ahrens et al. 2012). 
In its simplest form, the consumption rate is defined as:

$Q_{i j}\left(B_{i}, B_{j}\right)=\frac{v_{i j} \cdot a_{i j} \cdot B_{i} \cdot B_{j}}{v_{i j}^{\prime}+v_{i j}+a_{i j} \cdot B_{j}}$

where, for prey group $i$ and predator $j, Q$ is consumption; $B$ is biomass; $a$ is effective search rate; $v$ is vulnerability to predation exchange rate; and $v$ ' is invulnerable to predation exchange rate.

The foraging area concept implies that predators, over time, may greatly vary the composition their diets with fluctuations of available prey.

\section{Ecospace}

The spatial-temporal module of EwE, Ecospace, extends the Ecosim parameter set with extra parameters related to spatial preferences and movement. Ecospace executes the Ecosim equations across a two-dimensional grid of equally sized cells, where functional groups and fishing effort gravitate towards better conditions (Walters et al. 1999, Christensen et al. 2014). Cells can be blocked out from having ecosystem dynamics to represent land (for marine ecosystems) or cells that fall beyond the modelled area of interest.

\section{Species dynamics}

Ecospace contains a highly configure niche model that defines cell suitability for functional groups. Central to this concept is the term of 'capacity', or 'habitat foraging capacity' in full, which defines the suitability of functional groups to forage across the spatial grid (Christensen et al. 2014). Ecospace affects the capacity of a predator to forage as follows:

$V=\frac{v B}{v+v^{\prime}+a P / A}$

where, for a given predator, $V$ is vulnerable prey density; $B$ is prey biomass, $P$ is predator abundance; $v$ and $v$ ' are vulnerability exchange rates to and from the feeding arena; $a$ is search rate; and $A$ is the foraging arena size.

The niche model can derive its capacity, per cell, per group, per time step, from three different pathways:

1. Through habitats (spatial distributions of relevant spatial features) and habitat preferences (the ability to use each habitat for a given group)

2. Through environmental drivers (spatial distributions of relevant environmental parameters) and environmental responses (functional response curves that quantify the tolerance or preference of a given group to a specific environmental driver)

3. Through external forcing, in case an external species distribution model is used.

Habitat capacity $C h$ is defined as the total suitability of a cell for a species to feed due to the presence of preferred habitats: 


$$
C h_{i}=\sum_{h=1}^{n} r_{h} \cdot p_{i, h} ; \quad C h_{i} \in[0,1] ; r_{h} \in[0,1] ; p_{i, h} \in[0,1]
$$

where, for functional group $i$ and habitat $h, C h$ is habitat capacity; $n$ is the number of habitats; $r$ is the ratio of the cell area covered by a habitat; $p$ is habitat preference of a group to a specific habitat.

Environmental capacity $\mathrm{Ce}$, on the other hand, is defined as the multiplicative assessment of environmental preferences:

$$
C e_{i}=\prod_{e=1}^{m} Y_{i, e} ; \quad C e_{i} \in[0,1]
$$

where, for functional group $i$ and environmental driver $e, C e$ is environmental capacity; $m$ is the number of environmental drivers, and $Y$ is the environmental preference of group $i$ to environmental condition $e$ as dynamically evaluated across the spatial grid (Fig. 1).

Environmental
preference
functions $F_{i}$

The total capacity $C_{i}$ in a cell for a functional group is then simply defined as:

$$
C_{i}=C h_{i} \cdot C e_{i} ; \quad C e_{i} \in[0,1]
$$

Note that EwE release 6.5 introduces the flexibility to derive capacity from habitats alone (Eq. 4), from environmental responses alone (Eq. 5), or from both (Eq. 6). This is a per-group setting.

Functional groups in Ecospace will gravitate towards better nearby conditions, with better feeding opportunities are lower risk to predation. A set of specific parameters controls functional group movement: dispersal (average distance a group moves, during the Ecopath period, while searching for food), advection (current-induced movement), and migration (directed behavioral movement patterns). Groups can also be coaxed to stay out of 'bad' habitat, where risk to predation can be higher, and increased movement rates serve to return 
to more suitable habitat. Ecospace considers a cell as bad habitat for a given group when the available foraging arena size drops to $10 \%$ or below (Christensen et al. 2015).

\section{Fleet dynamics}

Fishing intensity in Ecospace is inherited from the base intensity specified in Ecopath, and its temporal fluctuations in Ecosim, and is expressed as a spatial distribution of effort for each fishing fleet in the model. Fishing effort is distributed across the Ecospace grid based on a simple economic evaluation, which balances the financial returns of catching target groups and their market value, against combined fixed fishing costs and catch per unit of effort (CPUE).

Ecospace offers four mechanisms to control fishing effort, per fleet, and its spatial distribution:

1. The total amount of Ecospace fishing effort can be increased or decreased through a fishing effort multiplier;

2. Habitats can be used to prohibit fishing for specific fishing gear types over unsuitable bottom types;

3. No-fishing zones (generally referred to a Marine Protected Area or MPA) can be established to close specific cells to specific fishing gear types, too (Walters et al. 2000);

4. The CPUE component of the economic evaluation can be affected by entering a distribution of relative fishing costs across the spatial grid, making specific map areas more expensive for fishing than others (Walters et al. 1999, Bauer et al. 2018). Although typically used to incorporate distance from port as an economic evaluation factor, this mechanism can also receive inverted historical fishing effort distributions to coax Ecospace to mimic observed fishing patterns. 


\section{LITERATURE CITED}

Ahrens, R. N. M., C. J. Walters, and V. Christensen. 2012. Foraging arena theory. Fish and Fisheries 13(1):41-59.

Bauer, B., H. E. M. Meier, M. Casini, A. Hoff, P. Margoński, A. Orio, S. Saraiva, J.

Steenbeek, and M. T. Tomczak. 2018. Reducing eutrophication increases spatial extent of communities supporting commercial fisheries: a model case study. ICES Journal of Marine Science.

Christensen, V., M. Coll, J. Buszowski, W. W. L. Cheung, T. Frölicher, J. Steenbeek, C. A. Stock, R. Watson, and C. J. Walters. 2015. The global ocean is an ecosystem:

Simulating marine life and fisheries. Global Ecology and Biogeography 24(5):507517.

Christensen, V., M. Coll, J. Steenbeek, J. Buszowski, D. Chagaris, and C. J. Walters. 2014. Representing Variable Habitat Quality in a Spatial Food Web Model. Ecosystems:116.

Christensen, V., and D. Pauly. 1992. ECOPATH II-a software for balancing steady-state ecosystem models and calculating network characteristics. Ecological modelling 61(3-4):169-185.

Christensen, V., and C. J. Walters. 2004. Ecopath with Ecosim: methods, capabilities and limitations. Ecological Modelling 172(2-4):109-139.

Polovina, J. J. 1984. Model of a coral reef ecosystem. Coral reefs 3(1):1-11.

Walters, C. J., D. Pauly, and V. Christensen. 1999. Ecospace: Prediction of Mesoscale Spatial Patterns in Trophic Relationships of Exploited Ecosystems, with Emphasis on the Impacts of Marine Protected Areas. Ecosystems 2(6):539-554.

Walters, C., D. Pauly, V. Christensen, and J. F. Kitchell. 2000. Representing Density Dependent Consequences of Life History Strategies in Aquatic Ecosystems: EcoSim II. Ecosystems 3(1):70-83. 